\title{
COVID-19 Shuts Doors to Flu but Keeps Them Open to Rhinoviruses
}

\author{
Irina Kiseleva 1,*(D) and Andrey Ksenafontov ${ }^{2}$ \\ 1 Department of Virology, Institute of Experimental Medicine, 197376 Saint Petersburg, Russia \\ 2 Department of Etiology and Epidemiology, Smorodintsev Research Institute of Influenza, \\ 197376 Saint Petersburg, Russia; ksenandrey@yandex.ru \\ * Correspondence: irina.v.kiseleva@mail.ru
}

check for updates

Citation: Kiseleva, I.; Ksenafontov, A. COVID-19 Shuts Doors to Flu but Keeps Them Open to Rhinoviruses. Biology 2021, 10, 733. https:// doi.org/10.3390/biology10080733

Academic Editors: Mohamad Goldust, Robert A. Schwartz, Dedee Murrell and Torello Lotti

Received: 14 June 2021

Accepted: 28 July 2021

Published: 31 July 2021

Publisher's Note: MDPI stays neutral with regard to jurisdictional claims in published maps and institutional affiliations.

Copyright: (c) 2021 by the authors Licensee MDPI, Basel, Switzerland. This article is an open access article distributed under the terms and conditions of the Creative Commons Attribution (CC BY) license (https:/ / creativecommons.org/licenses/by/ $4.0 /)$.
Simple Summary: Ten years have passed since the beginning of the H1N1pdm09 flu pandemic. No sooner had humanity recovered from its consequences than a new attack came-the COVID-19 pandemic. What happens to other respiratory infectious diseases during a global disaster such as the COVID-19 pandemic? The pandemic brought about by the novel SARS-CoV-2 virus has disrupted many well-established epidemiological and pathogenetic relationships, as well as mechanisms affecting infections with other respiratory viruses. The level of circulation of many respiratory pathogens has changed significantly. For instance, global influenza activity is at much lower levels than expected. In many regions, the influenza season has not started. Intriguingly, the COVID-19 pandemic did not substantially affect the spread of human rhinoviruses. In this review, the main properties of epidemiologically significant respiratory viruses such as SARS-CoV-2, influenza virus, and human rhinovirus are described.

Abstract: It is well known that rhinoviruses are distributed across the globe and are the most common cause of the common cold in all age groups. Rhinoviruses are widely considered to be harmless because they are generally perceived as respiratory viruses only capable of causing mild disease. However, they may also infect the lower respiratory tract, inducing chronic obstructive pulmonary disease and exacerbations of asthma, bronchiolitis, etc. The role of rhinoviruses in pathogenesis and the epidemiological process is underestimated, and they need to be intensively studied. In the light of recent data, it is now known that rhinoviruses could be one of the key epidemiological barriers that may influence the spread of influenza and novel coronaviruses. It has been reported that endemic human rhinoviruses delayed the development of the H1N1pdm09 influenza pandemic through viral interference. Moreover, human rhinoviruses have been suggested to block SARS-CoV-2 replication in the airways by triggering an interferon response. In this review, we summarized the main biological characteristics of genetically distinct viruses such as rhinoviruses, influenza viruses, and SARS-CoV-2 in an attempt to illuminate their main discrepancies and similarities. We hope that this comparative analysis will help us to better understand in which direction research in this area should move.

Keywords: acute viral respiratory infections; pandemics; epidemics; influenza; SARS-CoV-2; COVID-19; influenza A virus; human rhinovirus

\section{Introduction}

Influenza and the common cold, also known simply as the cold, are acute viral infections of the upper respiratory tract. The common cold is known as one of the most ubiquitous infectious diseases in humans. In total, more than several hundred viral types are associated with acute viral respiratory infections. The most commonly implicated are human rhinoviruses (HRVs), which are the cause of more than half of all common colds [1]; human coronaviruses, accounting for $10-15 \%$ of colds; human respiratory syncytial viruses (HRSVs), also called human orthopneumoviruses, which are the most common cause of 
respiratory hospitalization in infants (up to 60\%); influenza viruses; adenoviruses; human parainfluenza; and metapneumoviruses [1,2].

It is believed that viral colds are mostly self-limited infectious diseases that typically resolve within 8-10 days and are not serious illnesses [3]. However, the role of respiratory viruses-in particular, human rhinoviruses-in the total mass of respiratory pathogens cannot be underestimated. Rhinoviruses are ubiquitous respiratory tract pathogens. They affect the respiratory tract from its upper to lower parts, causing common colds, but have also been associated with pneumonia, asthma exacerbations, and wheezing [4]. In most cases, rhinoviruses as typical common cold pathogens lead to a short self-limiting illness. Most patients infected with HRVs are asymptomatic or suffer only mild symptoms [5]. However, for immunocompromised patients, the elderly, and asthmatics, HRV infections can lead to critical complications [6].

In addition, rhinoviruses are unique pathogens whose circulation is not affected by cataclysms such as epidemics and pandemics. As over 100 serotypes of HRVs exist, little immunological protection is provided to humans by prior rhinovirus infection, which accounts for the high incidence of subsequent infections [6]. However, the significant number of serotypes does not explain why rhinoviruses did not disappear during pandemics. Many other respiratory viruses, such as human adenoviruses, also have a large number of serotypes [7], but this did not help them to survive in the COVID-19 pandemic.

At the beginning of the spread of SARS-CoV-2 around the world, it was suggested that the pandemic would likely develop in accordance with one of two scenarios: (i) SARS-CoV-2 viruses would co-circulate with other viral respiratory pathogens, or (ii) SARS-CoV-2 viruses would displace them [8]. However, as the pandemic developed, it became clear that a third, combined scenario might have taken place. It was reported that the co-circulation of different respiratory viruses with SARS-CoV-2 strains could lead to both cooperative (rhinoviruses) and competitive (influenza viruses) forms of virus-virus interactions.

What happened to rhinoviruses in the COVID-19 era? What happened to other respiratory viruses in the COVID-19 era? What allowed two viruses-SARS-CoV-2 and rhinoviruses - to coexist peacefully, while SARS-CoV-2 displaced the influenza virus? In order to attempt to understand what unites these three respiratory viruses (SARS-CoV-2, influenza A virus, and human rhinovirus) and what the differences between them are, below we compared them according to several main characteristics. The results of this search are summarized in Tables 1-3.

\section{Virus Taxonomy}

All three viruses belong to the kingdom Orthornavirae [7]. One of them, influenza A virus (IAV), belongs to the phylum Negarnaviricota, and two others, HRVs and SARSCoV-2, are members of the class Pisoniviricetes, phylum Pisuviricota (Figure 1). Based on phylogeny, taxonomy, and established practice, the International Committee on Taxonomy of Viruses recognizes SARS-CoV-2 as forming a sister clade to the prototype of the species SARS-related coronavirus [9]. To date, HRVs continue to co-circulate together with another representative of class Pisoniviricetes, SARS-CoV-2 [10]. In contrast, representatives of the phylum Negarnaviricota, human influenza viruses, demonstrated a mysterious phenomenon of the displacement of previously circulating influenza viruses by a new pandemic of SARSCoV-2 [11-13].

What distinguishes the representatives of these two phyla? Why do some circulate in the COVID-19 pandemic while others do not? 


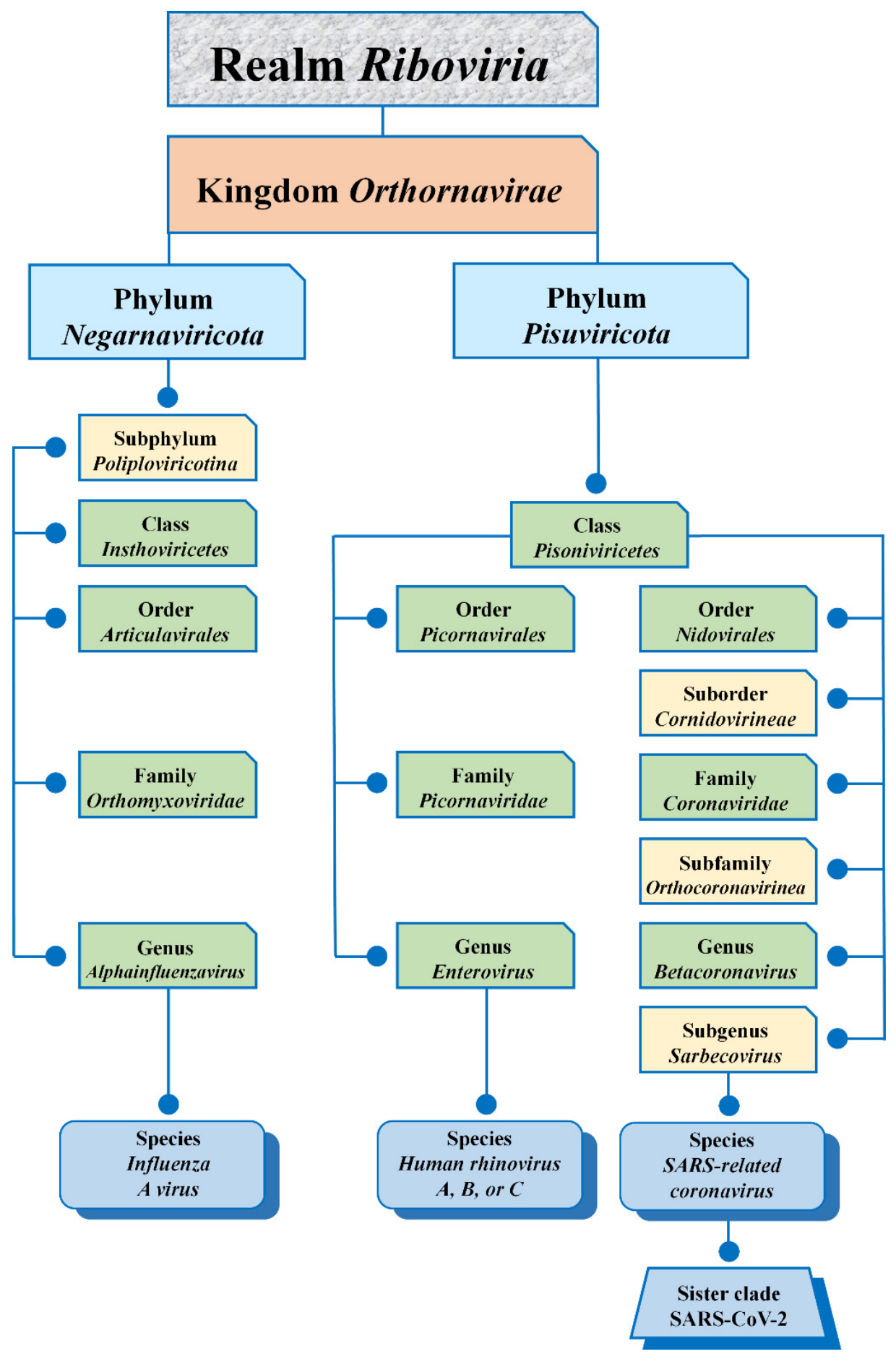

Figure 1. Taxonomic information on the three respiratory viruses discussed in this review $[7,9]$.

\section{Virion Morphology}

Fully developed infectious viral particles of IAV, SARS-CoV-2, and HRV are composed of RNA surrounded by a protein coating. All these viruses assemble an icosahedral capsid with a cubical symmetry type (Table 1 ).

By conventional negative-staining electron microscopy, virions of SARS-CoV-2 and influenza A virus appear to be roughly spherical or pleiomorphic and medium-sized in diameter; surface projections are comprised of spike glycoproteins. In contrast, human rhinoviruses have smaller sizes [14]. 
Table 1. Comparative characteristics of HRV, IAV, and SARS-CoV-2: organization and replication.

\begin{tabular}{|c|c|c|c|}
\hline \multirow{2}{*}{ Properties [refs] } & \multicolumn{3}{|c|}{ Causative Agent } \\
\hline & Rhinovirus & Influenza a Virus & SARS-CoV-2 \\
\hline \multicolumn{4}{|c|}{ VIRION MORPHOLOGY [15-21] } \\
\hline Size (nucleocapsid diameter) & Small-sized $(\sim 30 \mathrm{~nm})$ & Medium-sized (80-120 nm) & Medium-sized ( 120 nm) \\
\hline Nucleocapsid symmetry & Icosahedral symmetry & Icosahedral symmetry & Icosahedral symmetry \\
\hline Shape & Spherical shape & $\begin{array}{l}\text { Spherical shape, sometimes } \\
\text { filamentous morphology }\end{array}$ & Spherical shape \\
\hline \multicolumn{4}{|c|}{ VIRION STRUCTURE [15-33] } \\
\hline Capsid (coat protein) & Yes & Yes & Yes \\
\hline Envelop & No & Yes & Yes \\
\hline Glycoprotein spike & No & HA and NA & S glycoprotein \\
\hline Polybasic cleavage site & No & Only in avian IAV & Yes \\
\hline $\begin{array}{l}\text { RNA dependent RNA } \\
\text { polymerase }\end{array}$ & Yes & Yes & Yes \\
\hline HA esterase glycoprotein & No & No & Yes \\
\hline \multicolumn{4}{|c|}{ PHYSICOCHEMICAL PROPERTIES $[2,33,34]$} \\
\hline Thermostability & $\begin{array}{l}\text { Environmentally stable to } \\
\text { temperature (heat-resistant) }\end{array}$ & $\begin{array}{l}\text { Environmentally labile to } \\
\text { temperature (heat-sensitive) }\end{array}$ & $\begin{array}{l}\text { Environmentally labile to } \\
\text { temperature (heat-sensitive) }\end{array}$ \\
\hline Stability to drying & Stable to drying & Disrupted by drying & Disrupted by drying \\
\hline Stability to detergents & Stable to detergents & Disrupted by detergents & Disrupted by detergents \\
\hline Acid stability, pH sensitivity & Unstable below pH 5-6 & Disrupted by acid & Disrupted by acid \\
\hline \multicolumn{4}{|c|}{ GENOME ORGANIZATION $[22,26,27]$} \\
\hline Nucleic acid structure & RNA & RNA & RNA \\
\hline Size & $\sim 7 \mathrm{~kb}$ & $\sim 14 \mathrm{~kb}$ & $\sim 30 \mathrm{~kb}$ \\
\hline Type of nucleic acid molecule & Linear & Linear & Linear \\
\hline Helix form of nucleic acid & Single-stranded & Single-stranded & Single-stranded \\
\hline $\begin{array}{l}\text { Segmented/nonsegmented } \\
\text { genome }\end{array}$ & Nonsegmented & Segmented & Nonsegmented \\
\hline $\begin{array}{c}\text { Positive/negative-strand } \\
\text { RNA }\end{array}$ & Positive-sense RNA & Negative-sense RNA & Positive-sense RNA \\
\hline \multicolumn{4}{|c|}{ VIRAL REPLICATION [2,22,29,35-41] } \\
\hline Recognition and attachment & $\begin{array}{l}\text { A canyon in VP1 protein is the } \\
\text { site of the attachment of sialic } \\
\text { acids to the cell surface }\end{array}$ & $\begin{array}{l}\text { Binding to sialic acids on a } \\
\text { host cell by the } \\
\text { receptor-binding domain } \\
\text { of HA1 }\end{array}$ & $\begin{array}{l}\text { Binding to the cell surface } \\
\text { protein ACE } 2 \text { by } S \text { protein }\end{array}$ \\
\hline Entry into the host-cell & Endocytosis, pinocytosis & Endocytosis & $\begin{array}{l}\text { Endocytosis or at plasma } \\
\text { membrane fusion }\end{array}$ \\
\hline $\begin{array}{l}\text { Infectivity of naked } \\
\text { genomic RNA }\end{array}$ & Infectious & Not infectious & Infectious \\
\hline Transcription and replication & Cytoplasm & Nucleus & Cytoplasm \\
\hline Synthesis of viral proteins & Cytoplasm & Cytoplasm & Cytoplasm \\
\hline Virion assembly & Cytoplasm & Cytoplasm & Cytoplasm \\
\hline Virion release & Lytic or non-lytic releases & Budding & Exocytosis \\
\hline
\end{tabular}




\section{Virion Structure}

All viruses are categorized into two types based on their outer structure: (i) enveloped and (ii) non-enveloped [31]. IAV and SARS-CoV-2 are known to be lipid-enveloped viruses. The virion envelope of IAV and SARS-CoV-2 is derived from the cell membrane, incorporating virus glycoproteins and non-glycosylated proteins.

The lipid envelope of SARS-CoV-2 contains an envelope protein, a spike protein $\mathrm{S}$, and a membrane protein. The nucleocapsid protein forms the virion core encased in the viral genome [17]. The $S$ protein mediates viral binding to the host cell surface [28]. SARS-CoV-2 incorporates a polybasic cleavage site which is known to be responsible for increased transmissibility and pathogenicity in other viruses-for instance, avian IAV. In addition, SARS-CoV-2 possesses hemagglutinin esterase glycoprotein, which is used as an invading mechanism.

The influenza A virus particle is surrounded by a lipid bilayer which contains two main glycoproteins - hemagglutinin (HA) and neuraminidase (NA) — as well as the ion channel M2 protein. The inner surface envelops the M1 protein and the nuclear export protein (NEP) is located under the viral lipid bilayer. A complex made up of three polymerase subunits, PB2, PB1, and PA, is known as the viral RNA-dependent RNA polymerase [22].

In contrast, the virion structure of non-enveloped human rhinovirus is simpler [25]; its capsid is not covered by a lipid envelope [29] and is comprised of four viral structural proteins-VP1, VP2, VP3, and VP4. VP1 is the largest and most surface-exposed protein of the virus capsid. The remaining viral proteins are responsible for viral replication and subsequent assembly [18]. The virus capsid proteins exhibit a high degree of heterogeneity, resulting in a wide antigenic diversity [14,29]. Several antigenic sites have been identified for HRVs through studying the binding of neutralizing antibodies. Three distinct species of human rhinoviruses are currently known: HRV-A, HRV-B, and HRV-C. In total, over 170 types of HRV-A, HRV-B, and HRV-C were identified to be in circulation [30].

\section{Physicochemical Properties}

\subsection{Environment}

When discussing enveloped vs. non-enveloped viruses, the first thing that must be addressed is the outer protective covering surrounding enveloped viruses. However, being lipid-enveloped viruses, IAV and SARS-CoV-2 are environmentally labile to temperature (heat-sensitive) [42-45]; they are also disrupted by acids, detergents, and drying [42-50]. Viral particles are sensitive to oxidizing agents, lipid solvents, UV irradiation, and formaldehyde [48]. In contrast, non-enveloped rhinoviruses are environmentally more stable in elevated temperatures-they tolerate hot temperatures, displaying excellent heat-resistant properties, and can easily withstand a dry and acidic environment [51-55]. Compared to enveloped viruses, non-enveloped viruses are generally more powerful and proliferate rapidly in an acidic environment [56-59]. However, in contrast to many other nonenveloped picornaviruses [56,57], HRVs are acid-sensitive $[2,34,56]$ and unstable below pH 5-6 [33,56] (Table 1).

\subsection{Stability}

Due to their complex outer structure, enveloped viruses including IAV and SARSCoV-2 tend to show a higher stability and survive longer due to their adaptability to different environmental conditions [49,60]. In contrast, due to their virion structure and low resistance to the harsh environment, rhinoviruses are less stable than enveloped viruses and, therefore, survive for a shorter time in the host as well as outside the host environment $[2,56]$.

\subsection{Sterilization}

Rhinoviruses, as with any non-enveloped viruses, are difficult to sterilize, as they can easily adjust to changes in temperature [56]. Enveloped viruses, on the other hand, 
are easier to sterilize because they do not show a high resistance to desiccation and heat treatment [53].

\section{Genome Organization}

There are differences in the genomic organization of SARS-CoV-2, HRV, and IAV. One out of the three viruses discussed, IAV, contains a negative genome, (-)RNA; two others possess positive-sense viral RNA, (+)RNA. All of them are single-stranded RNA viruses of a linear type of nucleic acid molecule. IAV contains segmented RNA and its genome consists of eight segmented genes of varying lengths: PB2, PB1, PA, HA, NP, NA, M, and NS. Each viral RNA genome segment encodes at least one protein [26] and is associated with a protein complex [22,27]. In contrast, the genomes of both SARS-CoV-2 and HRV are nonsegmented.

\section{Viral Replication}

The main stages of the viral replication cycle of IAV, HRV, and SARS-CoV-2 are presented in Table 1.

Viruses have specific receptors on the host cells that they attach to, and, in turn, each virus has a particular viral protein that binds the cell attachment receptor. All three viruses hijack the cell via endosomes $[2,29,37,39]$. SARS-CoV-2 can also enter cells via plasma membrane fusion [36].

The major surface protein of the HRV capsid, VP1, plays an important role in the attachment to the surface of a host cell $[2,29,37]$. After binding and endocytosis in the cell, single-stranded positive polar RNA migrates across the endosomal membrane into the cytoplasm. All stages of HRV replication, including virion assembly, occur in the host cell's cytoplasm [35]. In the late stage of infection, mature virions are released from the cell by lysis or via non-lytic release [35].

SARS-CoV-2 attaches to host cells using the cell surface protein ACE2 (angiotensinconverting enzyme 2 ) through the receptor-binding domain of the spike (S) protein $[37,41]$ which mediates SARS-CoV-2 entry into cells [36]. Moreover, similar to certain enveloped viruses, SARS-CoV-2 possesses a glycoprotein hemagglutinin, esterase, which is involved in the virus invading and attaching. The coronavirus genomic RNA encodes structural, nonstructural, and accessory proteins [61]. Nonstructural proteins play key roles in viral RNA synthesis, while structural proteins are important for virion assembly. SARS-CoV-2 mature virions leave the infected cell through the mechanism of exocytosis. The accessory proteins are not directly involved in viral replication but interfere with the host's innate immune response [62,63].

Individual spikes on the virion of the IAV that attach/bind to the cell receptor-sialic acid-are molecules of the hemagglutinin. Attachment to the host cell occurs through the receptor-binding domain, which is located in the HA1 [39]. IAV entry also involves the HA and occurs through receptor-mediated endocytosis. NA is responsible for the release of mature viral particles from infected host cells. M1 protein is involved in virion assembly and budding, and the nuclear export protein NEP plays a role in the nuclear export of viral ribonucleoprotein complexes. The core of the IAV is made up of the eight viral RNA segments (genes) that are encapsidated by the viral nucleoprotein. Each ribonucleoprotein (RNP) complex is associated with a viral RNA-dependent RNA polymerase complex made up of the three polymerase subunits PB2, PB1, and PA, which, together with the viral NP, are the essential proteins required for viral replication and transcription. The multipotent enzymes of negative-strand RNA viruses, RNA-dependent RNA polymerases, transcribe and replicate the viral genome in the host [22]. Importantly, in contrast to HRV and SARS-CoV-2, virion RNA synthesis occurs in the nucleus.

Host cells do not normally replicate RNA; thus, RNA viruses must encode an enzyme, RNA polymerase (RNA-dependent RNA polymerase), which is required for genome replication and the production of mRNA. RNA-dependent RNA polymerase is an essential 
protein encoded in the genomes of all RNA-containing viruses with no DNA stage [64,65], including SARS-CoV-2 [66].

For all (-)RNA viruses, including IAV, the most important event in infection is the synthesis of mRNAs from the negative-sense genomic RNA by the RNA-dependent RNA polymerase. The mRNAs are translated into a single protein or more than one product. The naked genomes of (-)RNA viruses are not infectious, nor are they complementary RNA copies of the genomes [66,67].

For viruses with a positive-sense genome, following virus entry into the host cell the first step in replication is the translation of the incoming genomic (+)RNA, mRNA, on cytoplasmic ribosomes to produce proteins which are required for the synthesis of antigenomic copies of the genomic (+)RNA. As the replication cycle of $(+)$ RNA viruses begins in the translation of the $(+)$ RNA genome in order to produce RNA synthesis enzymes, the naked RNA is infectious. In other words, the introduction of the genomic RNA into a susceptible cell will result in a complete infection cycle $[66,68]$. New virions form by budding, thereby incorporating matrix proteins and viral RNPs that align below the plasma membrane regions containing viral envelope proteins.

New viral particles are released from the infected cell through budding (IAV), exocytosis (SARS-CoV-2), or lytic or non-lytic mechanisms (HRVs).

\section{Pathogenesis}

\subsection{Temperature Sensitivity of Replication}

As temperature-sensitive pathogens, human rhinoviruses have a relatively low optimum temperature for replication in HeLa cell culture, $33^{\circ} \mathrm{C}$, which reflects their adaptation for replication in the nasopharyngeal region $[2,69]$. However, some HRVs are temperatureresistant and may multiply at a higher temperature of $37^{\circ} \mathrm{C}$ [52,70]. In MDCK cells, typical influenza A viruses may replicate in a wide range of temperatures from 32 to $38^{\circ} \mathrm{C}$ [71]. In eggs, the cut-off temperature of IAVs is even higher and reaches $40^{\circ} \mathrm{C}[72,73]$. SARS-CoV-2 can also efficiently replicate in Vero cells in the range of $33-37^{\circ} \mathrm{C}$ [74]. The ability of respiratory viruses to replicate in vitro out of a temperature optimum confirms the fact that these viruses can also infect the lower respiratory tract, thus causing its damage (Table 2).

\subsection{Differences and Similarities between Influenza and COVID-19}

The influenza virus and SARS-CoV-2 cause an acute respiratory infection that can manifest itself in a variety of ways, from asymptomatic to severe and even fatal. There are several differences between SARS-CoV-2 and influenza A virus pathogenesis. For instance, the IAV has a shorter incubation period and a shorter interval between subsequent infections. It is about 1-4 days, while in the case of a disease caused by SARS-CoV-2, it is up to 14 days. Although the symptoms of both diseases are similar, the proportion of patients with severe disease is different.

The clinical picture of COVID-19 is similar to that of influenza and many other acute viral respiratory infections: fatigue, breathing difficulties, cough or sore throat, fever, muscle pain, headache, nausea, insomnia, diarrhea, vomiting, etc. (see Section 9 below). A hallmark event is increasing shortness of breath, which may indicate the development of pneumonia. Complications from severe COVID-19 include the following: pneumonia, sepsis and septic shock, acute respiratory distress syndrome, heart injury, acute kidney injury, meningoencephalitis, myocarditis, gastrointestinal problems (especially in children), thrombosis, and renal failure [92].

COVID-19 can also cause neurological complications [93]. Most people with severe COVID-19 infection appear to recover without experiencing significant mental illness. Delirium may feature in the acute stages of COVID-19. Unfortunately, little is known about the pathogenesis of SARS-CoV-2 infection in the central nervous system. Kumari et al. [94] suggested that the direct infection of cells of the central nervous system together with the inflammatory response induced in the brain result in severe disease. As for influenza, the proportion of severe and extremely severe cases and complications is lower [95-97]. 
Table 2. Comparative characteristics of the common cold, influenza, and COVID-19: pathogenesis.

\begin{tabular}{|c|c|c|c|}
\hline \multirow{2}{*}{ Properties [refs] } & \multicolumn{3}{|c|}{ Causative Agent } \\
\hline & Rhinovirus & Influenza Virus & SARS-CoV-2 \\
\hline \multicolumn{4}{|c|}{ PATHOGENESIS AND CLINICAL FEATURES [1-4,21,52,69-104] } \\
\hline $\begin{array}{l}\text { "Entrance gate" of infection } \\
\text { (the primary route of entry) }\end{array}$ & $\begin{array}{l}\text { Upper respiratory tract } \\
\text { (mouth and nose) }\end{array}$ & $\begin{array}{l}\text { Upper respiratory tract } \\
\text { (mouth and nose) }\end{array}$ & $\begin{array}{l}\text { Upper respiratory tract } \\
\text { (mouth and nose) }\end{array}$ \\
\hline $\begin{array}{l}\text { Upper respiratory } \\
\text { tract infection }\end{array}$ & Common & Common & Common \\
\hline $\begin{array}{c}\text { Replication at } \\
\text { high temperature }\end{array}$ & Sometimes & Common & Common \\
\hline $\begin{array}{l}\text { Lower respiratory } \\
\text { tract infection }\end{array}$ & Sometimes & Sometimes & Common \\
\hline Incubation period & $1-3$ days & $1-4$ days & 2-14 days \\
\hline Symptoms & Gradual & Abrupt & Gradual \\
\hline Sudden onset & Smooth onset & Very common early symptom & Sudden or smooth onset \\
\hline Running nose (rhinorrhea) & Common & Common & Common \\
\hline Nasal discharge & Common & Common & Common \\
\hline Nasal congestion & Common & Sometimes & Common \\
\hline Sneezing & Very common & Sometimes & Common \\
\hline Loss of smell and taste & Rare & Sometimes & Very common early symptom \\
\hline Shortness of breath & Mild & Sometimes & Common \\
\hline Sore throat & Very common & Sometimes & Sometimes/common \\
\hline Cough & $\begin{array}{l}\text { Common (mild to } \\
\text { moderate, hacking) }\end{array}$ & $\begin{array}{l}\text { Common (dry cough, } \\
\text { can be severe) }\end{array}$ & $\begin{array}{l}\text { Common (dry cough, } \\
\text { can be severe) }\end{array}$ \\
\hline Headache & Rare & Common & Common \\
\hline Muscle pain (body aches) & Sometimes (slight) & Very common (often severe) & Very common (often severe) \\
\hline Chilliness and fever & $\begin{array}{l}\text { Rare in adults, possible in } \\
\text { children }\end{array}$ & Very common; may have chills & Very common; may have chills \\
\hline Malaise & Sometimes & Very common & Very common \\
\hline Fatigue, weakness & Sometimes & $\begin{array}{c}\text { Very common } \\
\text { (can last for weeks) }\end{array}$ & $\begin{array}{c}\text { Very common } \\
\text { (can last for weeks) }\end{array}$ \\
\hline Diarrhea & Rare & Sometimes & Sometimes \\
\hline Loss of appetite & Sometimes & Common & Sometimes \\
\hline
\end{tabular}

\subsection{Pathogenesis of Rhinovirus Infection}

The primary route of entry for HRVs, IAVs, and SARS-CoV-2 is the upper respiratory tract (mouth and nose). Rhinovirus infection of the nasopharyngeal mucosa does not cause symptoms of acute viral respiratory infection directly, instead initiating an inflammatory response that produces the symptoms [3]. Some inflammatory pathways, including neurologic reflexes triggered by the infection, have been identified as playing key roles in the pathogenesis of rhinovirus infection [98].

Generally, rhinovirus infection is mild and self-limiting, but it may also be associated with bronchiolitis (in infants), pneumonia (in the immunocompromised), and exacerbation (in patients with pulmonary conditions) [87]. HRVs are the major pediatric pathogens that affect both the upper and lower respiratory tracts and frequently cause wheezing, asthma exacerbations, and pneumonia $[4,70]$. A defective immune response to rhinovirus infection involving interferon-lambda is considered as one of the mechanisms behind exacerbations in asthmatic children [4]. 
Unlike the influenza virus, human rhinovirus does not cause cytopathic changes in the nasal epithelial cells [99]. However, it can cause cytopathology in the bronchial epithelium [70] and disruption in the epithelial barrier of the airway [100,101].

\section{Clinical Manifestations}

In general, the respiratory symptoms are typical for the majority of upper respiratory viral infections [1] and about the same for all viral pathogens. Studies on the symptoms specific to different respiratory viruses have indicated that it is not possible to identify the exact causative virus based on the symptoms alone, since similar symptoms are caused by different viruses [88]. It is difficult to define respiratory symptoms exactly because of the great variation in their severity, duration, and type [1]. With regard to particulars, COVID-19 is closer to influenza than to other upper respiratory viral infections due to the presence and severity of respiratory symptoms. There is much overlap in the symptomatology of common cold and influenza symptoms. A common early symptom of influenza is sudden onset $[85,86]$; other acute viral respiratory infections are characterized by a smoother onset, with loss of taste and smell as early distinguishing symptoms of COVID-19 [84].

The cold syndrome, including the infection caused by rhinovirus, has been defined as a short mild illness with early symptoms of sneezing, headache, stuffy nose, chilliness, and sore throat, as well as later symptoms of nasal obstruction, nasal discharge, body aches, possibly cough, and malaise [102]. Generally, the severity of symptoms increases rapidly, peaking 2-3 days after infection, with a mean duration of symptoms of 7-10 days.

In contrast, the most common symptoms of COVID-19 include headache, fever, loss of smell and taste, cough, nasal obstruction, asthenia, myalgia, rhinorrhea, gustatory dysfunction, shortness of breath, sore throat, body aches, fatigue, possibly diarrhea, and vomiting $[89,103]$ (Table 2). There is some evidence to suggest that patients who have suffered from mild or severe COVID-19 can experience prolonged symptoms or develop long-term complications [103]. The risk of severe disease and death is higher in people who are older, male, and from deprived areas. Children and infants generally appear to experience milder symptoms than adults [103].

Influenza syndrome is typically characterized by fever, myalgia, headache, cough, nasal congestion, sore throat, loss of appetite, and weakness [1].

\section{Epidemiology}

10.1. Origin

The source of the COVID-19 outbreak has yet to be determined. It is suggested that COVID-19 likely has a zoonotic origin [105-107]. Alternatively, a human-made origin of SARS-CoV-2 has also been discussed. The influenza A virus causes human disease through strains that appear through the seasonal variation of human influenza viruses and through pandemic infection resulting from viral reassortment or the adaptation of zoonotic influenza viruses, thus introducing antigenically novel variants into the human population [108]. Rhinoviruses seem likely not to have arisen from a recent zoonotic event $[109,110]$.

\subsection{Transmission}

HRV, IAV, and SARS-CoV-2 are respiratory pathogens that are transmitted by classical airborne droplets.

The person-to-person transmission of SARS-CoV-2 has occurred extensively. The transmission risk is the highest if people are in a close distance of within $2 \mathrm{~m}$. The human-tohuman transmission of novel coronaviruses mainly occurs through the spread of droplets or direct contact from the sneezing or coughing of an infected individual [82,103]. In addition to respiratory secretions, SARS-CoV-2 has been detected in feces, blood, and urine.

Yan et al. [111] proved that the influenza virus likely spreads by aerosols, not just coughs or sneezes. People infected with influenza can pass the virus to others just by 
breathing, with the role of transmission from coughing and sneezing smaller than previously thought. The transmission of the influenza A virus occurs mainly before symptoms appear, and for SARS-CoV-2 infection so-called "asymptomatic transmission" is possible.

The transmission of rhinovirus occurs by small- and large-particle aerosols or through direct contact [112]. To cause infection, the virus must be deposited on the nasal mucosa or conjunctiva; some believe that oral inoculation is not sufficient $[3,51,113]$. Feasible mechanisms for rhinovirus transmission are also hand-to-hand and hand-to-surface-tohand transfer. Additionally, self-inoculation appears to be an effective means of rhinovirus transmission in the home environment. HRVs can remain viable for a few hours or up to 4 days on suitable surfaces $[51,98,114]$. This finding supports the possibility of selfinoculation by fomites.

\subsection{Seasonality}

SARS-CoV-2, much like influenza, tends to be a winter virus that feels more comfortable in cold and dry air [115]. However, so far, such conclusions should be drawn with caution. We know too little about whether the COVID-19 coronavirus is seasonal or not (Table 3).

HRV infections occur throughout all seasons but frequently peak in autumn and spring $[87,98,116-118]$. Their infection rate varies throughout the year due to the prevalence of other more seasonal respiratory viruses. However, epidemiologic data seem to suggest that the relative number of rhinovirus infections occurring during the year is fairly constant [98].

\subsection{Morbidity, Hospitalization, and Mortality}

The impact of respiratory virus infections on morbidity, hospitalization, and mortality in patients has been widely studied. In this review, we will restrict ourselves to the most general, global data. All three infections-influenza, the common cold, and COVID-19are distributed worldwide. How do indicators of the severity of illness (incidence rate, hospitalization rate, and death rate) compare for these three infections?

The WHO estimates that, worldwide, annual influenza epidemics result in about one billion cases of infection [119], about 9,460,000 hospitalizations with severe illness [120], and about 410,000 deaths [121]. This estimate excludes the global incidence of influenza and deaths during the COVID-19 pandemic.

The global incidence of COVID-19 is different. The annual death rate from the COVID19 results is about 2.8-6.2 times higher than that of seasonal influenza (ratios were calculated based on data from [120-122]). The rate of annual infection with SARS-CoV-2 is about $83,560,000$ and the hospitalization rate is about $15,800,000$ cases.

Table 3. Comparative characteristics of the common cold, influenza, and COVID-19: epidemiology.

\begin{tabular}{|c|c|c|c|}
\hline \multirow{2}{*}{ Properties [refs] } & \multicolumn{3}{|c|}{ Causative Agent } \\
\hline & Rhinovirus & Influenza Virus & SARS-CoV-2 \\
\hline \multicolumn{4}{|c|}{ EPIDEMIOLOGY $[1,10,11,82,84,86,88-90,120,123-131]$} \\
\hline Origin & $\begin{array}{c}\text { Likely not arisen from a recent } \\
\text { zoonotic event }\end{array}$ & $\begin{array}{c}\text { Likely not arisen from a recent } \\
\text { zoonotic event except } \\
\text { pandemic strains }\end{array}$ & $\begin{array}{l}\text { No conclusive evidence yet. } \\
\text { Likely zoonotic origin }\end{array}$ \\
\hline Transmission & $\begin{array}{l}\text { Mainly through direct contact } \\
\text { with aerosolized particles } \\
\text { from an infected individual }\end{array}$ & $\begin{array}{l}\text { Through the spread of } \\
\text { droplets or direct contact by } \\
\text { sneezing or coughing from an } \\
\text { infected individual }\end{array}$ & $\begin{array}{l}\text { Through the spread of } \\
\text { droplets or direct contact by } \\
\text { sneezing or coughing from an } \\
\text { infected individual }\end{array}$ \\
\hline World distribution & Worldwide & Worldwide & Worldwide \\
\hline $\begin{array}{c}\text { Seasonality } \\
\text { (circulation pattern) }\end{array}$ & $\begin{array}{c}\text { Cold seasons, but is possible } \\
\text { year-round }\end{array}$ & Cold seasons (fall and winter) & $\begin{array}{l}\text { No conclusive evidence yet. } \\
\text { Possibly cold seasons }\end{array}$ \\
\hline Level of transmissibility & Moderate & High & High \\
\hline
\end{tabular}


Table 3. Cont.

\begin{tabular}{|c|c|c|c|}
\hline \multirow{2}{*}{ Properties [refs] } & \multicolumn{3}{|c|}{ Causative Agent } \\
\hline & Rhinovirus & Influenza Virus & SARS-CoV-2 \\
\hline $\begin{array}{l}\text { Annually infected } \\
\text { (global), thds }\end{array}$ & No global data available & $\sim 1,000,000$ & $\sim 83,600$ \\
\hline $\begin{array}{l}\text { Hospitalization rate } \\
\text { (global), thds }\end{array}$ & No global data available & $\sim 9460$ & $\sim 15,800$ \\
\hline Annual death (global), thds & No global data available & $\sim 410$ & $\sim 1800$ \\
\hline $\begin{array}{l}\text { Prevalence and incidence of } \\
\text { the disease }\end{array}$ & Local outbreaks & Epidemics, pandemics & Pandemic \\
\hline $\begin{array}{l}\text { Circulation during an } \\
\text { influenza epidemic season }\end{array}$ & Does not change & $\begin{array}{l}\text { Circulation of seasonal } \\
\text { influenza viruses }\end{array}$ & Yes \\
\hline $\begin{array}{l}\text { Circulation during an } \\
\text { influenza pandemic }\end{array}$ & Does not change & $\begin{array}{l}\text { Decreased circulation of } \\
\text { seasonal influenza viruses }\end{array}$ & Not applicable \\
\hline $\begin{array}{l}\text { Circulation during the } \\
\text { COVID-19 pandemic }\end{array}$ & Does not change & $\begin{array}{l}\text { Decreased circulation of } \\
\text { seasonal influenza viruses }\end{array}$ & Yes \\
\hline
\end{tabular}

Despite HRV being the most common cause of acute viral respiratory infections and it being found year-round, the global burden of the disease and the global case count attributable to rhinovirus are unknown, most likely because rhinovirus surveillance is not yet well established. This may be due to the relatively mild course of rhinovirus infection. However, country-specific information is available for some countries. For instance, according to the Pan American Health Organization (PAHO), there are about 16,000 laboratory-confirmed rhinovirus infection cases in North America (average data from 2017 to 2020), with an average of 695 cases in Central America over the same period, and 185 rhinovirus cases in South America [132]. No statistics on hospitalization and mortality are available.

\subsection{Prevalence and Incidence of the Disease}

In contrast to HRVs, which cause local outbreaks only, type A influenza is the cause of epidemics and pandemics. As for COVID-19, scientists around the world are discussing the important question of whether SARS-CoV-2 will become a seasonal virus [133-135]. The majority of experts are sure that COVID-19 may eventually become a seasonal illness similar to influenza, but the virus will continue to spread year-round until the entire population achieves herd immunity.

\subsection{Circulation}

Novel coronavirus SARS-CoV-2 spread throughout the world very quickly. On 31 December 2019, the WHO China Country Office was first informed of a cluster of cases of pneumonia of unknown cause detected in China [103]. As of 20 July 2021, globally there have been 190,770,507 confirmed cases of COVID-19, including 4,095,924 deaths, reported to the WHO [122]. According to the information of the WHO [122] and Johns Hopkins University, today over 190 countries have reported cases of COVID-19 infection [136].

The common cold is an illness that frequently affects humans of all ages [98]. For most of the year, the most frequent human acute viral respiratory infections across all age groups are associated with HRVs [137]. Rhinoviruses disproportionately affect young children [98]. Adults usually catch colds from children [98]. Interestingly, adults who live with young children experience more colds than other adults living without young children [3]. The continuous invasion and high diversity of rhinoviruses have been observed [138]. Rhinovirus activity has been detected in countries of all continents: Spain [139], Brazil [140-142], Argentina [143], France [125], Italy [10,144], the United Kingdom [116], Russia [145], Finland [146,147], Canada [148], the US [3,102,137,149-151], Australia [152], Vietnam [153], 
China [154,155], Hong Kong [156], Japan [157], Burundi [158], KwaZulu-Natal (a province of South Africa) [159], Tanzania [90], and many others, including Antarctica [160].

Seasonal human influenza viruses circulate in all parts of the world. They cause a year-round disease burden [161].

\section{Interactions between Rhinoviruses and Other Respiratory Viruses during Their Co-Circulation}

As was mentioned above, the emergence of the recent 2019 novel coronavirus was associated with substantial reductions in the circulation of seasonal respiratory viruses. Pool et al. [162] reported that, before 2020, the most frequently detected non-COVID-19 virus was influenza, followed by rhinovirus. During the first wave of the 2020 pandemic, a significant drop in the circulation of non-COVID-19 respiratory viruses compared to previous years was detected; among them, the most common non-SARS-CoV-2 virus detected was HRV.

The possible impact of rhinoviruses on some other respiratory pathogens has been highlighted in the literature $[125-127,130,163]$. It has been shown that HRVs can both coexist with other respiratory viruses and compete with them. The mutual effects between HRVs, influenza viruses, and SARS-CoV-2 during their co-circulation manifest in several scenarios: (i) the spread of influenza viruses is delayed by seasonal HRVs $[10,123,125,163,164]$ or (ii) by the SARS-CoV-2 pandemic [13]; in turn, pandemic SARS-CoV-2 (iii) can be blocked by HRVs [126] or (iv) co-circulate with them [10] (Figure 2).

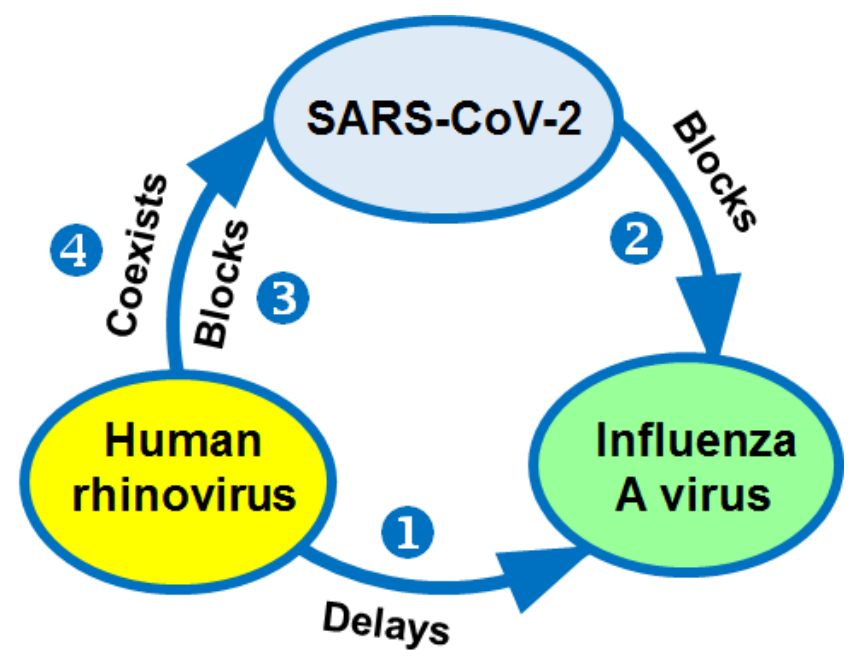

Figure 2. Interactions between human rhinoviruses, influenza A virus, and SARS-CoV-2 (based on the results and suggestions of $[10,126,128,163,165])$.

\subsection{The Spread of the Influenza A Virus Might Be Interrupted by HRV}

A nine-year analysis of 44,230 cases of respiratory illness in Glasgow, UK, revealed that interplay between a ubiquitous human rhinovirus during its peak activity and seasonal influenza A virus can diminish the activity of the latter [166].

Some believed that interference between rhinovirus and the H1N1pmd09 virus disrupted the pandemic in Europe. Data from a number of European countries pointed out that the circulation of the H1N1pdm09 influenza A pandemic virus might be interrupted by the annual autumn rhinovirus epidemic $[128,165]$. Other studies have also demonstrated that the annual rhinovirus delayed the spread of the novel pandemic H1N1pdm09 influenza virus $[123,163]$. The researchers explained this phenomenon by the fact that infection with rhinovirus may inhibit subsequent influenza infection by activating antiviral defenses in the airway mucosa, which is a target tissue of both viruses. These results confirmed that viral interference could affect the course of an influenza epidemic or even pandemic.

As we mentioned above, rhinoviruses have long been known as one of the most frequent causes of colds. Moreover, they are also present at high rates in asymptomatic 
people. Moreover, such asymptomatic infections can trigger interferon-stimulated gene expression in the upper respiratory epithelium $[167,168]$. Thus, rhinovirus infections might protect the host by blocking infection by viruses of higher virulence.

\subsection{Influenza Viruses Are Delayed in Spread by SARS-CoV-2}

The world has experienced five viral pandemics in the last hundred years; in particular, four pandemics occurred due to influenza A viruses and the last one occurred due to SARSCoV-2. In each known influenza pandemic, the causative pandemic strain has replaced the previous seasonal virus. According to the latest update of the WHO, as of 5 July 2021 global influenza activity was at lower levels than expected for this time of the year.

In the Northern Hemisphere, influenza activity returned to inter-seasonal levels, while in the Southern Hemisphere the influenza season has not started yet [13]. Most countries reported the sporadic detection of influenza to the WHO, though many areas are experiencing a high rate of COVID-19 cases [13]. In areas where COVID-19 is widespread, the circulation of influenza viruses is still significantly reduced.

Notably, throughout the pandemic caused by SARS-CoV-2, there has been a $99 \%$ reduction in influenza virus isolation globally [12]. The most common co-infections in the COVID-19 pandemic were HRV, HRSV, and non-SARS-CoV-2 coronaviruses. The lowest levels of detection of co-infection with SARS-CoV-2 were influenza and adenoviruses [11]. It is anticipated that influenza will re-emerge following the SARS-CoV-2 pandemic and circulate again [12].

\subsection{HRV Van Block SARS-CoV-2}

Competitive relationships have been registered not only for HRV+IAV but also for the HRV+SARS-CoV-2. According to the extraordinary study of the MRC-University of Glasgow Centre for Virus Research [126], HRV infection can block SARS-CoV-2 replication in cells of the respiratory tract by triggering an interferon response, and it may reduce COVID-19 severity and disease burden.

\subsection{SARS-CoV-2 Can Co-Circulate with Other Respiratory Pathogens}

A study performed in Italy during the wintertime between December 2019 and March 2020 showed an interesting trend in the dissemination of respiratory pathogens; HRV (22.3\%) and HRSV (23.7\%) were found to be the most commonly identified viruses, followed by SARS-CoV-2 (14.1\%) [10].

Wu et al. [128] suggested that the annual rhinovirus outbreaks may determine the timing and severity of seasonal influenza epidemics and the ongoing COVID-19 pandemic. These data indicate the necessity of an update of the current conception of rhinovirus infection. The tragic events of 2019-2021 highlight the necessity of understanding and predicting the circulation of ubiquitous respiratory viruses during the COVID-19 pandemic to design effective anti-pandemic measures.

\section{A Brief Summary of the Main Similarities and Differences between SARS-CoV-2, IAV, and HRV}

Human rhinoviruses are distributed globally and cause acute viral respiratory infections across all age groups [118]. They have long been considered relatively harmless viruses and have been undeservedly neglected in the past because they were generally perceived as respiratory viruses only capable of causing a mild common cold [100]. Of course, the statement that HRVs are one of the most common causes of mild respiratory infections is correct. However, they also induce aggravations of asthma; chronic obstructive pulmonary disease; bronchiolitis in young children; and infections of the lower respiratory tract in children, the elderly, and immunosuppressed patients. Antigenic diversity and a large number of HRVs (currently over 170) are significant obstacles in rhinovirus vaccine development [169].

Moreover, in the light of recent data, it became known that rhinoviruses may not only coexist in parallel with other respiratory viruses but also compete with them (Figure 2). 
This suggests that the role of rhinoviruses in the epidemiological process is underestimated and that they need to be comprehensively studied. Until now, it has not been clear as to why rhinoviruses continue to circulate and even delay the spread of SARS-CoV-2 [126] or H1N1pdm09 viruses $[123,125,163,164]$, while seasonal influenza viruses are being supplanted by the novel pandemic coronavirus $[13,130]$.

How distant or similar is the human rhinovirus to the influenza A virus and SARSCoV-2? In Tables 1-3, we can see how many features distinguish rhinoviruses from influenza viruses. IAV and SARS-CoV-2 are known to be viruses of medium size. Their capsid is covered by a lipid envelope. The influenza A virus contains negative-sense single-stranded segmented RNA, classified within the Orthomyxoviridae. The flu A virus has a small genome $(\sim 14 \mathrm{~kb})$ encoded in eight strands of RNA, and it infects human cells differently than coronaviruses [170]. Non-enveloped human rhinoviruses are a small-sized pathogen that possess a positive-sense single-stranded RNA $(\sim 7 \mathrm{~kb})$ and are classified within the Picornaviridae.

SARS-CoV-2 possesses positive-sense viral nonsegmented RNA; it is a member of the family Coronaviridae. Interestingly, coronaviruses have the largest genomes of any known RNA viruses $(\sim 30 \mathrm{~kb})$. These large genomes have led some to suspect the presence of a so-called "proofreading mechanism" to reduce the mutation rate and stabilize the viral genome. Indeed, coronaviruses have a proofreading exonuclease ExoN, which explains their relatively low mutation rates $\left(\sim 10^{-6}\right.$ per site per cycle) if compared to the influenza virus $\left(\sim 3 \times 10^{-5}\right.$ per site per cycle) [171]. Bar-On et al. [170] suggested that "This relatively low mutation rate will be of interest for future studies predicting the speed with which novel coronaviruses can evade our immunization efforts" [170].

HRV, IAV, and SARS-CoV-2 have many biological properties in common: they are found worldwide and are the most frequent RNA respiratory viruses associated with globally distributed respiratory infections. Alternatively, apart from the dissimilarities in their structure, these viruses exhibit different biological characteristics too, although their differences in clinical presentation are not so pronounced that we can identify the causative agent of the acute respiratory infection exactly. Although the respiratory symptoms of both diseases are similar, the proportion of patients with severe disease is higher for patients infected with SARS-CoV-2. The influenza A virus has a shorter incubation period than SARS-CoV-2.

Seasonal variations with predominance during cold seasons are typical for rhinovirus infections [116,141]. Influenza viruses circulate in the winter season [172]. Regarding SARS-CoV-2, it is too early to talk about the seasonality of its distribution. Six months after the beginning of the COVID-19 pandemic, the WHO suggested that the new coronavirus is not seasonal, differing from other coronaviruses, and does not occur in waves. "It's going to be one big wave," WHO spokesperson Dr. Margaret Harris said during a press conference in July 2020 [173]. The position of the WHO was that COVID-19 is not affected by cold temperatures in a manner similar to seasonal influenza nor by heat, and there is no evidence that COVID-19 will follow seasonal variations. It has been suggested that season does affect the transmission of the virus because a large number of COVID-19 cases are associated with cold and dry climates in temperate regions of the world. Thus, the seasonality of the SARS-CoV-2 spread is suspected [174]; there are concerns that SARS-CoV-2 may establish itself as an endemic human respiratory coronavirus [175].

Interestingly, in the pathogenesis of rhinovirus infection, there is a very important point that distinguishes rhinoviruses from other respiratory pathogens and brings them closer to coronaviruses. In contrast to many other respiratory viruses, the clinical symptoms of HRV infection are primarily caused by the host's immune response to infection rather than by viral cytopathicity [176]. Intriguingly, whether during COVID-19 or influenza pandemics, HRVs are the most common viruses detected in patients meeting the appropriate clinical criteria for presentation to hospitals or clinics. Rhinoviruses, therefore, create an enormous socio-economic burden across the globe [110,177]. Maybe this is an answer to many of the questions raised. 
It is speculated that any of the properties listed in Tables $1-3$ or their combinations may somehow affect the uniqueness of the epidemiological process during rhinovirus infection in the COVID-19 era. Which of these are key points, individually or collectively, and whether they are is not known to us.

Not everything is so simple-for instance, this scheme does not fit HRSV, which is known to circulate at approximately the same intensity as rhinoviruses and does not disappear during COVID-19 or influenza pandemics. At the same time, there is little in common between such phylogenetically distant viruses as HRSV and rhinoviruses. HRSV is a member of the phylum Negarnaviricota, together with the influenza A virus [33]. By virion organization, this medium-sized virus which possesses a negative-sense RNA genome [32,33] is closer to the influenza virus. In terms of its structural and biological characteristics, there are far more differences than similarities between HRVs and HRSVs.

Thus, among all the viral characteristics presented above, there are no common global features uniting HRVs and HRSVs that could explain why their unique circulation is not affected by other viral pathogens. Phylogenetically and in terms of their main biological properties, they are very distant each from other. Their membership in the same kingdom of Orthornavirae is unlikely to play a key role. It is most likely that the reason for this lies in the yet-undiscovered subtle molecular mechanisms of infections caused by these agents.

\section{Conclusions}

"I know that I know nothing..."

-Socratic paradox

Many questions remain open: what allows some respiratory pathogens such as SARSCoV-2 and HRV to coexist, while SARS-CoV-2 displaces influenza viruses and some others? What is the reason for the peculiar coexistence of the two distinct respiratory pathogens, the ubiquitous human rhinoviruses first discovered in the 1950s and the newly emerged SARS-CoV-2?

In nature, there are two different outcomes of competition between the two species: (i) competitive exclusion or (ii) coexistence. Competition is a situation where two different species can compete for the same abiotic resource. If competing species make use of the resources available in the environment in different ways, they can coexist in the same area. Can we attribute the first scenario to influenza viruses, adenoviruses, etc., and the second scenario to HRVs? There are still too many "white spots" for us to draw conclusions about this. Much about coronaviruses is still unclear.

What conclusions is it possible for us to draw at the moment? We know what the viruses we discussed in this review have in common and how they differ. We do know that the circulation of rhinoviruses is independent of the epidemiological process of other infections. However, we do not know why.

Collectively, new clinical findings and experimental insights relating to human rhinovirus should stimulate renewed interest in studying all common cold viruses, including rhinoviruses.

Author Contributions: Conceptualization, I.K.; writing-original draft preparation, I.K., A.K.; writing—review and editing, I.K.; visualization, I.K., A.K.; supervision, I.K.; project administration, I.K.; funding acquisition, I.K. Both authors have read and agreed to the published version of the manuscript.

Funding: Russian Science Foundation provided the funds to support the publication of this article (RSF grant agreement number 21-75-30003).

Institutional Review Board Statement: Not applicable.

Informed Consent Statement: Not applicable.

Data Availability Statement: Not applicable. 
Conflicts of Interest: The authors declare no conflict of interest. The funders had no role in the design of the study; in the collection, analyses, or interpretation of data; in the writing of the manuscript, or in the decision to publish the results.

\section{References}

1. Eccles, R. Understanding the symptoms of the common cold and influenza. Lancet Infect. Dis. 2005, 5, 718-725. [CrossRef]

2. Jacobs, S.E.; Lamson, D.M.; St. George, K.; Walsh, T.J. Human rhinoviruses. Clin. Microbiol. Rev. 2013, 26, 135. [CrossRef]

3. Pappas, D.E.; Hendley, J.O. The common cold and decongestant therapy. Pediatr. Rev. 2011, 32, 47-54. [CrossRef]

4. Drysdale, S.B.; Mejias, A.; Ramilo, O. Rhinovirus-not just the common cold. J. Infect. 2017, 74 (Suppl. S1), S41-S46. [CrossRef]

5. Self, W.H.; Williams, D.J.; Zhu, Y.; Ampofo, K.; Pavia, A.T.; Chappell, J.D.; Hymas, W.C.; Stockmann, C.; Bramley, A.M.; Schneider, E.; et al. Respiratory viral detection in children and adults: Comparing asymptomatic controls and patients with community-acquired pneumonia. J. Infect. Dis. 2016, 213, 584-591. [CrossRef]

6. Charles, C.H.; Yelmene, M.; Luo, G.X. Recent advances in rhinovirus therapeutics. Curr. Drug Targets Infect. Disord. 2004, 4, 331-337. [CrossRef]

7. ICTV. Virus Taxonomy: 2020 Release. Available online: https://talk.ictvonline.org/taxonomy/ (accessed on 30 July 2021).

8. Kiseleva, I.; Grigorieva, E.; Larionova, N.; Al Farroukh, M.; Rudenko, L. COVID-19 in light of seasonal respiratory infections. Biology 2020, 9, 240. [CrossRef]

9. Gorbalenya, A.E.; Baker, S.C.; Baric, R.S.; de Groot, R.J.; Drosten, C.; Gulyaeva, A.A.; Haagmans, B.L.; Lauber, C.; Leontovich, A.M.; Neuman, D.W.; et al. The species severe acute respiratory syndrome-related coronavirus: Classifying 2019-nCoV and naming it SARS-CoV-2. Nat. Microbiol. 2020, 5, 536-544. [CrossRef]

10. Calderaro, A.; De Conto, F.; Buttrini, M.; Piccolo, G.; Montecchini, S.; Maccari, C.; Martinelli, M.; Di Maio, A.; Ferraglia, F.; Pinardi, F.; et al. Human respiratory viruses, including SARS-CoV-2, circulating in the winter season 2019-2020 in Parma, Northern Italy. Int. J. Infect. Dis. 2020, 102, 79-84. [CrossRef]

11. Kim, D.; Quinn, J.; Pinsky, B.; Shah, N.H.; Brown, I. Rates of co-infection between SARS-CoV-2 and other respiratory pathogens. JAMA 2020, 323, 2085-2086. [CrossRef]

12. Laurie, K.L.; Rockman, S. Which influenza viruses will emerge following the SARS-CoV-2 pandemic? Influenza Other Respir Viruses 2021. [CrossRef]

13. WHO. Overview of Influenza Activity Globally. Influenza Update $\mathrm{N}^{\circ} 397$ of 5 July 2021. Available online: https: / www.who.int/ publications/m/item/influenza-update-n-397 (accessed on 20 July 2021).

14. Waman, V.P.; Kolekar, P.S.; Kale, M.M.; Kulkarni-Kale, U. Population structure and evolution of rhinoviruses. PLoS ONE 2014, 9, e88981. [CrossRef]

15. Griffiths, C.; Drews, S.J.; Marchant, D.J. Respiratory syncytial virus: Infection, detection, and new options for prevention and treatment. Clin. Microbiol. Rev. 2017, 30, 277-319. [CrossRef]

16. Selvaraj, M.; Yegambaram, K.; Todd, E.; Richard, C.A.; Dods, R.L.; Pangratiou, G.M.; Trinh, C.H.; Moul, S.L.; Murphy, J.C.; Mankouri, J.; et al. The structure of the human respiratory syncytial virus M2-1 protein bound to the interaction domain of the phosphoprotein $p$ defines the orientation of the complex. mBio 2018, 9. [CrossRef]

17. Barreto-Vieira, D.F.; da Silva, M.A.N.; Garcia, C.C.; Miranda, M.D.; Matos, A.D.R.; Caetano, B.C.; Resende, P.C.; Motta, F.C.; Siqueira, M.M.; Girard-Dias, W.; et al. Morphology and morphogenesis of SARS-CoV-2 in Vero-E6 cells. Mem Inst. Oswaldo Cruz 2021, 116, e200443. [CrossRef]

18. Hrebík, D.; Füzik, T.; Gondová, M.; Šmerdová, L.; Adamopoulos, A.; Šedo, O.; Zdráhal, Z.; Plevka, P. ICAM-1 induced rearrangements of capsid and genome prime rhinovirus 14 for activation and uncoating. Proc. Natl. Acad. Sci. USA 2021, 118. [CrossRef]

19. Coscio, F.; Nadra, A.; Ferreiro, D. A Structural Model for the Coronavirus Nucleocapsid. 2020. Available online: https: / / arxiv.org/pdf/2005.12165.pdf (accessed on 30 July 2021).

20. Peng, Y.; Du, N.; Lei, Y.; Dorje, S.; Qi, J.; Luo, T.; Gao, G.F.; Song, H. Structures of the SARS-CoV-2 nucleocapsid and their perspectives for drug design. EMBO J. 2020, 39, e105938. [CrossRef]

21. Akram, A.; Mannan, N. Molecular structure, pathogenesis and virology of SARS-CoV-2: A review. Bangladesh J. Infect. Dis. 2020, S36-S40. [CrossRef]

22. Breen, M.; Nogales, A.; Baker, S.F.; Martínez-Sobrido, L. Replication-competent influenza A viruses expressing reporter genes. Viruses 2016, 8, 179. [CrossRef]

23. Ke, Z.; Oton, J.; Qu, K.; Cortese, M.; Zila, V.; McKeane, L.; Nakane, T.; Zivanov, J.; Neufeldt, C.J.; Cerikan, B.; et al. Structures and distributions of SARS-CoV-2 spike proteins on intact virions. Nature 2020, 588, 498-502. [CrossRef] [PubMed]

24. Naqvi, A.A.T.; Fatima, K.; Mohammad, T.; Fatima, U.; Singh, I.K.; Singh, A.; Atif, S.M.; Hariprasad, G.; Hasan, G.M.; Hassan, M.I. Insights into SARS-CoV-2 genome, structure, evolution, pathogenesis and therapies: Structural genomics approach. Biochim. Biophys. Acta Mol. Basis Dis. 2020, 1866, 165878. [CrossRef] [PubMed]

25. Tuthill, T.J.; Groppelli, E.; Hogle, J.M.; Rowlands, D.J. Picornaviruses. Curr. Top. Microbiol. Immunol. 2010, 343, 43-89. [CrossRef]

26. Cheung, T.K.; Poon, L.L. Biology of influenza a virus. Ann. N. Y. Acad. Sci. 2007, 1102, 1-25. [CrossRef]

27. De Vlugt, C.; Sikora, D.; Pelchat, M. Insight into influenza: A virus cap-snatching. Viruses 2018, 10, 641. [CrossRef] 
28. Hoffmann, M.; Kleine-Weber, H.; Schroeder, S.; Krüger, N.; Herrler, T.; Erichsen, S.; Schiergens, T.S.; Herrler, G.; Wu, N.H.; Nitsche, A.; et al. SARS-CoV-2 cell entry depends on ACE2 and TMPRSS2 and is blocked by a clinically proven protease inhibitor. Cell 2020, 181, 271-280.e278. [CrossRef]

29. Stobart, C.C.; Nosek, J.M.; Moore, M.L. Rhinovirus biology, antigenic diversity, and advancements in the design of a human rhinovirus vaccine. Front. Microbiol. 2017, 8, 2412. [CrossRef]

30. McIntyre, C.L.; Knowles, N.J.; Simmonds, P. Proposals for the classification of human rhinovirus species A, B and C into genotypically assigned types. J. Gen. Virol. 2013, 94, 1791-1806. [CrossRef]

31. Sakudo, A.; Onodera, T.; Tanaka, Y. Inactivation of viruses. In Sterilization and Disinfection by Plasma: Sterilization Mechanisms, Biological and Medical Applications (Medical Devices and Equipment), 1st ed.; Sakudo, A., Shintani, H., Hauppauge, N.Y., Eds.; Nova Science Publishers: New York, NY, USA, 2010; pp. 49-60.

32. Collins, P.L.; Fearns, R.; Graham, B.S. Respiratory syncytial virus: Virology, reverse genetics, and pathogenesis of disease. Curr. Top. Microbiol. Immunol. 2013, 372, 3-38. [CrossRef]

33. ICTV. Virus Taxonomy. Classification and Nomenclature of Viruses. Ninth Report of the International Committee on Taxonomy of Viruses, 9th ed.; King, A.M.Q., Adams, M.J., Carstens, E.B., Lefkowitz, E.J., Eds.; Academic Press: London, UK, 2012.

34. Tyrrell, D.A.; Bynoe, M.L.; Hitchcock, G.; Pereira, H.G.; Andrewes, C.H. Some virus isolations from common colds. I. Experiments employing human volunteers. Lancet 1960, 1, 235-237. [CrossRef]

35. Baggen, J.; Thibaut, H.J.; Strating, J.; van Kuppeveld, F.J.M. The life cycle of non-polio enteroviruses and how to target it. Nat. Rev. Microbiol. 2018, 16, 368-381. [CrossRef]

36. Shang, J.; Wan, Y.; Luo, C.; Ye, G.; Geng, Q.; Auerbach, A.; Li, F. Cell entry mechanisms of SARS-CoV-2. Proc. Natl. Acad. Sci. USA 2020, 117, 11727-11734. [CrossRef]

37. Trougakos, I.P.; Stamatelopoulos, K.; Terpos, E.; Tsitsilonis, O.E.; Aivalioti, E.; Paraskevis, D.; Kastritis, E.; Pavlakis, G.N.; Dimopoulos, M.A. Insights to SARS-CoV-2 life cycle, pathophysiology, and rationalized treatments that target COVID-19 clinical complications. J. Biomed. Sci. 2021, 28, 9. [CrossRef]

38. O'Neill, R.E.; Talon, J.; Palese, P. The influenza virus NEP (NS2 protein) mediates the nuclear export of viral ribonucleoproteins. EMBO J. 1998, 17, 288-296. [CrossRef] [PubMed]

39. Dou, D.; Revol, R.; Östbye, H.; Wang, H.; Daniels, R. Influenza A virus cell entry, replication, virion assembly and movement. Front. Immunol. 2018, 9, 1581. [CrossRef]

40. Liao, L.E.; Kowal, S.; Cardenas, D.A.; Beauchemin, C.A.A. Exploring virus release as a bottleneck for the spread of influenza A virus infection in vitro and the implications for antiviral therapy with neuraminidase inhibitors. PLoS ONE 2017, 12, e0183621. [CrossRef]

41. Lu, R.; Zhao, X.; Li, J.; Niu, P.; Yang, B.; Wu, H.; Wang, W.; Song, H.; Huang, B.; Zhu, N.; et al. Genomic characterisation and epidemiology of 2019 novel coronavirus: Implications for virus origins and receptor binding. Lancet 2020, 395, 565-574. [CrossRef]

42. Henwood, A.F. Coronavirus disinfection in histopathology. J. Histotechnol. 2020, 43, 102-104. [CrossRef]

43. Dehbandi, R.; Zazouli, M.A. Stability of SARS-CoV-2 in different environmental conditions. Lancet Microbe 2020, 1, e145. [CrossRef]

44. Eslami, H.; Jalili, M. The role of environmental factors to transmission of SARS-CoV-2 (COVID-19). AMB Express 2020, 10, 92. [CrossRef]

45. Otter, J.A.; Donskey, C.; Yezli, S.; Douthwaite, S.; Goldenberg, S.D.; Weber, D.J. Transmission of SARS and MERS coronaviruses and influenza virus in healthcare settings: The possible role of dry surface contamination. J. Hosp. Infect. 2016, 92, 235-250. [CrossRef]

46. Hemalatha, M.; Kiran, U.; Kuncha, S.K.; Kopperi, H.; Gokulan, C.G.; Mohan, S.V.; Mishra, R.K. Surveillance of SARS-CoV-2 spread using wastewater-based epidemiology: Comprehensive study. Sci. Total Environ. 2021, 768, 144704. [CrossRef]

47. Mohan, S.V.; Hemalatha, M.; Kopperi, H.; Ranjith, I.; Kumar, A.K. SARS-CoV-2 in environmental perspective: Occurrence, persistence, surveillance, inactivation and challenges. Chem. Eng. J. 2021, 405, 126893. [CrossRef] [PubMed]

48. Sagripanti, J.L.; Lytle, C.D. Inactivation of influenza virus by solar radiation. Photochem. Photobiol. 2007, 83, 1278-1282. [CrossRef]

49. Hirose, R.; Ikegaya, H.; Naito, Y.; Watanabe, N.; Yoshida, T.; Bandou, R.; Daidoji, T.; Itoh, Y.; Nakaya, T. Survival of SARS-CoV-2 and influenza virus on the human skin: Importance of hand hygiene in COVID-19. Clin. Infect. Dis. 2020. [CrossRef]

50. Weber, T.P.; Stilianakis, N.I. Inactivation of influenza A viruses in the environment and modes of transmission: A critical review. J. Infect. 2008, 57, 361-373. [CrossRef]

51. Hendley, J.O.; Wenzel, R.P.; Gwaltney, J.M., Jr. Transmission of rhinovirus colds by self-inoculation. N. Engl. J. Med. 1973, 288, 1361-1364. [CrossRef]

52. Papadopoulos, N.G.; Sanderson, G.; Hunter, J.; Johnston, S.L. Rhinoviruses replicate effectively at lower airway temperatures. J. Med. Virol. 1999, 58, 100-104. [CrossRef]

53. Firquet, S.; Beaujard, S.; Lobert, P.E.; Sané, F.; Caloone, D.; Izard, D.; Hober, D. Survival of enveloped and non-enveloped viruses on inanimate surfaces. Microbes Environ. 2015, 30, 140-144. [CrossRef]

54. Kramer, A.; Schwebke, I.; Kampf, G. How long do nosocomial pathogens persist on inanimate surfaces? A systematic review. BMC Infect. Dis. 2006, 6, 130. [CrossRef]

55. Mahl, M.C.; Sadler, C. Virus survival on inanimate surfaces. Can. J. Microbiol. 1975, 21, 819-823. [CrossRef] 
56. Oliveira, A.C.; Ishimaru, D.; Gonçalves, R.B.; Smith, T.J.; Mason, P.; Sá-Carvalho, D.; Silva, J.L. Low temperature and pressure stability of picornaviruses: Implications for virus uncoating. Biophys. J. 1999, 76, 1270-1279. [CrossRef]

57. Pérez, L.; Carrasco, L. Entry of poliovirus into cells does not require a low-pH step. J. Virol. 1993, 67, 4543-4548. [CrossRef] [PubMed]

58. Geller, C.; Varbanov, M.; Duval, R.E. Human coronaviruses: Insights into environmental resistance and its influence on the development of new antiseptic strategies. Viruses 2012, 4, 3044-3068. [CrossRef]

59. Lamarre, A.; Talbot, P.J. Effect of $\mathrm{pH}$ and temperature on the infectivity of human coronavirus 229E. Can. J. Microbiol. 1989, 35, 972-974. [CrossRef] [PubMed]

60. Kormuth, K.A.; Lin, K.; Qian, Z.; Myerburg, M.M.; Marr, L.C.; Lakdawala, S.S. Environmental persistence of influenza viruses is dependent upon virus type and host origin. mSphere 2019, 4. [CrossRef]

61. Ju, X.; Zhu, Y.; Wang, Y.; Li, J.; Zhang, J.; Gong, M.; Ren, W.; Li, S.; Zhong, J.; Zhang, L.; et al. A novel cell culture system modeling the SARS-CoV-2 life cycle. PLoS Pathog. 2021, 17, e1009439. [CrossRef]

62. Fung, T.S.; Liu, D.X. Human coronavirus: Host-pathogen interaction. Annu. Rev. Microbiol. 2019, 73, 529-557. [CrossRef]

63. Liu, D.X.; Fung, T.S.; Chong, K.K.; Shukla, A.; Hilgenfeld, R. Accessory proteins of SARS-CoV and other coronaviruses. Antivirus Res. 2014, 109, 97-109. [CrossRef]

64. Koonin, E.V.; Gorbalenya, A.E.; Chumakov, K.M. Tentative identification of RNA-dependent RNA polymerases of dsRNA viruses and their relationship to positive strand RNA viral polymerases. FEBS Lett. 1989, 252, 42-46. [CrossRef]

65. Zanotto, P.M.; Gibbs, M.J.; Gould, E.A.; Holmes, E.C. A reevaluation of the higher taxonomy of viruses based on RNA polymerases. J. Virol. 1996, 70, 6083-6096. [CrossRef]

66. Strauss, J.H.; Strauss, E.G. Overview of viruses and virus infection. In Viruses and Human Disease, 2nd ed.; Strauss, J.H., Strauss, E.G., Eds.; Academic Press: London, UK, 2008; pp. 1-33. [CrossRef]

67. Strauss, J.H.; Strauss, E.G. Minus-strand RNA viruses. In Viruses and Human Disease, 2nd ed.; Strauss, J.H., Strauss, E.G., Eds.; Academic Press: London, UK, 2008; pp. 137-191. [CrossRef]

68. Strauss, J.H.; Strauss, E.G. Plus-strand RNA viruses. In Viruses and Human Disease, 2nd ed.; Strauss, J.H., Strauss, E.G., Eds.; Academic Press: London, UK, 2008; pp. 63-136. [CrossRef]

69. Savolainen, C.; Blomqvist, S.; Hovi, T. Human rhinoviruses. Paediatr. Respir. Rev. 2003, 4, 91-98. [CrossRef]

70. Papadopoulos, N.G.; Bates, P.J.; Bardin, P.G.; Papi, A.; Leir, S.H.; Fraenkel, D.J.; Meyer, J.; Lackie, P.M.; Sanderson, G.; Holgate, S.T.; et al. Rhinoviruses infect the lower airways. J. Infect. Dis. 2000, 181, 1875-1884. [CrossRef]

71. Kiseleva, I.; Su, Q.; Toner, T.J.; Szymkowiak, C.; Kwan, W.S.; Rudenko, L.; Shaw, A.R.; Youil, R. Cell-based assay for the determination of temperature sensitive and cold adapted phenotypes of influenza viruses. J. Virol. Methods 2004, 116, 71-78. [CrossRef]

72. Kiseleva, I.; Larionova, N.; Kuznetsov, V.; Rudenko, L. Phenotypic characteristics of novel swine-origin influenza A/California/07/2009 (H1N1) virus. Influenza Other Respir. Viruses 2010, 4, 1-5. [CrossRef] [PubMed]

73. Kiseleva, I.; Rekstin, A.; Al Farroukh, M.; Bazhenova, E.; Katelnikova, A.; Puchkova, L.; Rudenko, L. Non-mouse-adapted H1N1pdm09 virus as a model for influenza research. Viruses 2020, 12, 590. [CrossRef] [PubMed]

74. Laporte, M.; Raeymaekers, V.; Van Berwaer, R.; Vandeput, J.; Marchand-Casas, I.; Thibaut, H.J.; Van Looveren, D.; Martens, K.; Hoffmann, M.; Maes, P.; et al. The SARS-CoV-2 and other human coronavirus spike proteins are fine-tuned towards temperature and proteases of the human airways. PLoS Pathog. 2021, 17, e1009500. [CrossRef]

75. Chatterjee, S.K.; Saha, S.; Munoz, M.N.M. Molecular pathogenesis, immunopathogenesis and novel therapeutic strategy against COVID-19. Front. Mol. Biosci. 2020, 7, 196. [CrossRef] [PubMed]

76. Coleman, W.; Tsongalis, G. Understanding molecular pathogenesis. In Molecular Pathology, 2nd ed.; Coleman, W., Tsongalis, G., Eds.; Elsevier: Amsterdam, The Netherlands, 2018; pp. 231-242. [CrossRef]

77. Colman, H.; Aldape, K. Molecular pathogenesis. In Primary Central Nervous System Tumors, Current Clinical Oncology; Norden, A.D., Reardon, D.A.E.A., Eds.; Springer Science: Berlin, Germany, 2011; pp. 27-44. [CrossRef]

78. Horzinek, M.C. Molecular pathogenesis of virus infections. Experientia 1987, 43, 1193-1196. [CrossRef]

79. Mattoo, S.; Cherry, J.D. Molecular pathogenesis, epidemiology, and clinical manifestations of respiratory infections due to Bordetella pertussis and other Bordetella subspecies. Clin. Microbiol. Rev. 2005, 18, 326. [CrossRef] [PubMed]

80. Neumann, G.; Shinya, K.; Kawaoka, Y. Molecular pathogenesis of H5N1 influenza virus infections. Antivir. Ther. 2007, 12, 617-626.

81. Polo, J.M.; Davis, N.L.; Rice, C.M.; Huang, H.V.; Johnston, R.E. Molecular analysis of Sindbis virus pathogenesis in neonatal mice by using virus recombinants constructed in vitro. J. Virol. 1988, 62, 2124-2133. [CrossRef] [PubMed]

82. Rothan, H.A.; Byrareddy, S.N. The epidemiology and pathogenesis of coronavirus disease (COVID-19) outbreak. J. Autoimmun. 2020, 109, 102433. [CrossRef]

83. Patick, A.K. Rhinovirus chemotherapy. Antivir. Res. 2006, 71, 391-396. [CrossRef]

84. Dawson, P.; Rabold, E.M.; Laws, R.L.; Conners, E.E.; Gharpure, R.; Yin, S.; Buono, S.A.; Dasu, T.; Bhattacharyya, S.; Westergaard, R.P.; et al. Loss of taste and smell as distinguishing symptoms of coronavirus disease 2019. Clin. Infect. Dis. 2021, 72, 682-685. [CrossRef]

85. Monto, A.S.; Gravenstein, S.; Elliott, M.; Colopy, M.; Schweinle, J. Clinical signs and symptoms predicting influenza infection. Arch. Intern. Med. 2000, 160, 3243-3247. [CrossRef] 
86. Hak, E.; Moons, K.G.; Verheij, T.J.; Hoes, A.W. Clinical signs and symptoms predicting influenza infection. Arch. Intern. Med. 2001, 161, 1351-1352. [CrossRef]

87. Ortega, H.; Nickle, D.; Carter, L. Rhinovirus and asthma: Challenges and opportunities. Rev. Med. Virol. 2020, e2193. [CrossRef]

88. Tyrrell, D.A.; Cohen, S.; Schlarb, J.E. Signs and symptoms in common colds. Epidemiol. Infect. 1993, 111, 143-156. [CrossRef]

89. Lechien, J.R.; Chiesa-Estomba, C.M.; Place, S.; Van Laethem, Y.; Cabaraux, P.; Mat, Q.; Huet, K.; Plzak, J.; Horoi, M.; Hans, S.; et al. Clinical and epidemiological characteristics of 1420 European patients with mild-to-moderate coronavirus disease 2019. J. Intern. Med. 2020, 288, 335-344. [CrossRef]

90. L'Huillier, A.G.; Kaiser, L.; Petty, T.J.; Kilowoko, M.; Kyungu, E.; Hongoa, P.; Vieille, G.; Turin, L.; Genton, B.; D’ Acremont, V.; et al. Molecular epidemiology of human rhinoviruses and enteroviruses highlights their diversity in sub-Saharan Africa. Viruses 2015, 7, 6412-6423. [CrossRef] [PubMed]

91. Banerjee, A.; Baid, K.; Mossman, K. Molecular pathogenesis of middle east respiratory syndrome (MERS) coronavirus. Curr. Clin. Microbiol. Rep. 2019, 6, 139-147. [CrossRef] [PubMed]

92. Berlin, D.A.; Gulick, R.M.; Martinez, F.J. Severe COVID-19. N. Engl. J. Med. 2020, 383, 2451-2460. [CrossRef]

93. Carod-Artal, F.J. Neurological complications of coronavirus and COVID-19. Rev. Neurol. 2020, 70, 311-322. [CrossRef] [PubMed]

94. Kumari, P.; Rothan, H.A.; Natekar, J.P.; Stone, S.; Pathak, H.; Strate, P.G.; Arora, K.; Brinton, M.A.; Kumar, M. Neuroinvasion and encephalitis following intranasal inoculation of SARS-CoV-2 in K18-hACE2 mice. Viruses 2021, 13, 132. [CrossRef] [PubMed]

95. Beeching, N.J.; Fletcher, T.E.; Beadsworth, M.B.J. Covid-19: Testing times. BMJ 2020, 369, m1403. [CrossRef]

96. Hui, D.S.; E, I.A.; Madani, T.A.; Ntoumi, F.; Kock, R.; Dar, O.; Ippolito, G.; McHugh, T.D.; Memish, Z.A.; Drosten, C.; et al. The continuing 2019-nCoV epidemic threat of novel coronaviruses to global health-The latest 2019 novel coronavirus outbreak in Wuhan, China. Int. J. Infect. Dis. 2020, 91, 264-266. [CrossRef]

97. Wu, Z.; McGoogan, J.M. Characteristics of and important lessons from the coronavirus disease 2019 (COVID-19) outbreak in China: Summary of a report of 72314 cases from the Chinese Center for Disease Control and Prevention. JAMA 2020, 323, 1239-1242. [CrossRef]

98. Winther, B. Rhinoviruses. In International Encyclopedia of Public Health; Heggenhougen, H.K., Ed.; Academic Press: Oxford, UK, 2008; pp. 577-581. [CrossRef]

99. Winther, B.; Gwaltney, J.M.; Hendley, J.O. Respiratory virus infection of monolayer cultures of human nasal epithelial cells. Am. Rev. Respir. Dis. 1990, 141, 839-845. [CrossRef]

100. To, K.K.W.; Yip, C.C.Y.; Yuen, K.Y. Rhinovirus-from bench to bedside. J. Med. Assoc. 2017, 116, 496-504. [CrossRef]

101. Sajjan, U.; Wang, Q.; Zhao, Y.; Gruenert, D.C.; Hershenson, M.B. Rhinovirus disrupts the barrier function of polarized airway epithelial cells. Am. J. Respir. Crit. Care Med. 2008, 178, 1271-1281. [CrossRef]

102. Pappas, D.E.; Hendley, J.O.; Hayden, F.G.; Winther, B. Symptom profile of common colds in school-aged children. Pediatric Infect. Dis. J. 2008, 27, 8-11. [CrossRef]

103. GOV.UK. Guidance COVID-19: Epidemiology, Virology and Clinical Features. Updated 18 February 2021. Available online: https://www.gov.uk/government/publications/wuhan-novel-coronavirus-background-information/wuhan-novelcoronavirus-epidemiology-virology-and-clinical-features (accessed on 17 May 2021).

104. Jin, Y.; Yang, H.; Ji, W.; Wu, W.; Chen, S.; Zhang, W.; Duan, G. Virology, epidemiology, pathogenesis, and control of COVID-19. Viruses 2020, 12, 372. [CrossRef]

105. Contini, C.; Di Nuzzo, M.; Barp, N.; Bonazza, A.; De Giorgio, R.; Tognon, M.; Rubino, S. The novel zoonotic COVID-19 pandemic: An expected global health concern. J. Infect. Dev. Ctries. 2020, 14, 254-264. [CrossRef]

106. Guo, Y.R.; Cao, Q.D.; Hong, Z.S.; Tan, Y.Y.; Chen, S.D.; Jin, H.J.; Tan, K.S.; Wang, D.Y.; Yan, Y. The origin, transmission and clinical therapies on coronavirus disease 2019 (COVID-19) outbreak-an update on the status. Mil. Med. Res. 2020, 7, 11. [CrossRef]

107. Ghareeb, O.; Ramadhan, S. COVID-19-a novel zoonotic disease: Origin, prevention and control. Pak. J. Med. Health Sci. 2021, 15, 221-223.

108. Calder, L.J.; Wasilewski, S.; Berriman, J.A.; Rosenthal, P.B. Structural organization of a filamentous influenza A virus. Proc. Natl. Acad. Sci. USA 2010, 107, 10685-10690. [CrossRef] [PubMed]

109. Woolhouse, M.E.; Gowtage-Sequeria, S. Host range and emerging and reemerging pathogens. Emerg. Infect. Dis. 2005, 11, 1842-1847. [CrossRef]

110. Arden, K.E.; Mackay, I.M. Newly identified human rhinoviruses: Molecular methods heat up the cold viruses. Rev. Med. Virol. 2010, 20, 156-176. [CrossRef] [PubMed]

111. Yan, J.; Grantham, M.; Pantelic, J.; de Mesquita, J.B.; Albert, B.; Liu, F.; Ehrman, S.; Milton, D.; Consortium, E. Infectious virus in exhaled breath of symptomatic seasonal influenza cases from a college community. Proc. Natl. Acad. Sci. USA 2018, 115. [CrossRef] [PubMed]

112. Hendley, J.O.; Gwaltney, J.M., Jr. Mechanisms of transmission of rhinovirus infections. Epidemiol. Rev. 1988, 10, $243-258$. [CrossRef]

113. D'Alessio, D.J.; Meschievitz, C.K.; Peterson, J.A.; Dick, C.R.; Dick, E.C. Short-duration exposure and the transmission of rhinoviral colds. J. Infect. Dis. 1984, 150, 189-194. [CrossRef]

114. Mackay, I.M. Human rhinoviruses: The cold wars resume. J. Clin. Virol. 2008, 42, 297-320. [CrossRef]

115. Kudo, E.; Song, E.; Yockey, L.J.; Rakib, T.; Wong, P.W.; Homer, R.J.; Iwasaki, A. Low ambient humidity impairs barrier function and innate resistance against influenza infection. Proc. Natl. Acad. Sci. USA 2019, 116, 10905-10910. [CrossRef] [PubMed] 
116. Roebuck, M.O. Rhinoviruses in Britain 1963-1973. J. Hyg. 1976, 76, 137-146. [CrossRef] [PubMed]

117. Winther, B. Rhinovirus infections in the upper airway. Proc. Am. Thorac. Soc. 2011, 8, 79-89. [CrossRef] [PubMed]

118. Pitkäranta, A.; Hayden, F.G. Rhinoviruses: Important respiratory pathogens. Ann. Med. 1998, 30, 529-537. [CrossRef] [PubMed]

119. Krammer, F.; Smith, G.J.D.; Fouchier, R.A.M.; Peiris, M.; Kedzierska, K.; Doherty, P.C.; Palese, P.; Shaw, M.L.; Treanor, J.; Webster, R.G.; et al. Influenza. Nat. Rev. Dis. Prim. 2018, 4, 3. [CrossRef]

120. Troeger, C.E.; Blacker, B.F.; Khalil, I.A.; Zimsen, S.R.M.; Albertson, S.B.; Abate, D.; Abdela, J.; Adhikari, T.B.A.; Aghayan, S.A.; Agrawal, S.; et al. Mortality, morbidity, and hospitalisations due to influenza lower respiratory tract infections, 2017: An analysis for the Global Burden of Disease Study 2017. Lancet Respir. Med. 2019, 7, 69-89. [CrossRef]

121. Troeger, C.; Blacker, B.F.; Khalil, I.A.; Rao, P.C.; Cao, S.; Zimsen, S.R.M.; Albertson, S.; Stanaway, J.D.; Deshpande, A.; Farag, T.; et al. Estimates of the global, regional, and national morbidity, mortality, and aetiologies of lower respiratory infections in 195 countries, 1990-2016: A systematic analysis for the Global Burden of Disease Study 2016. Lancet Infect. Dis. 2018, 18, 1191-1210. [CrossRef]

122. WHO. Coronavirus Disease (COVID-19) Dashboard. Available online: https:/ / covid19.who.int/ (accessed on 20 July 2021).

123. Ånestad, G.; Nordbø, S.A. Does rhinovirus inhibit influenza A(H1N1) pandemic? Tidsskr. Nor. Laegeforen. 2010, 130, 1932-1934. [CrossRef]

124. Bulut, C.; Kato, Y. Epidemiology of COVID-19. Turk. J. Med. Sci. 2020, 50, 563-570. [CrossRef]

125. Casalegno, J.S.; Ottmann, M.; Duchamp, M.B.; Escuret, V.; Billaud, G.; Frobert, E.; Morfin, F.; Lina, B. Rhinoviruses delayed the circulation of the pandemic influenza A (H1N1) 2009 virus in France. Clin. Microbiol. Infect. 2010, 16, 326-329. [CrossRef]

126. Dee, K.; Goldfarb, D.M.; Haney, J.; Amat, J.A.R.; Herder, V.; Stewart, M.; Szemiel, A.M.; Baguelin, M.; Murcia, P.R. Human rhinovirus infection blocks SARS-CoV-2 replication within the respiratory epithelium: Implications for COVID-19 epidemiology. J. Infect. Dis. 2021. [CrossRef]

127. Nickbakhsh, S.; Ho, A.; Marques, D.F.P.; McMenamin, J.; Gunson, R.N.; Murcia, P.R. Epidemiology of seasonal coronaviruses: Establishing the context for COVID-19 emergence. J. Infect. Dis. 2020. [CrossRef]

128. Wu, A.; Mihaylova, V.T.; Landry, M.L.; Foxman, E.F. Interference between rhinovirus and influenza A virus: A clinical data analysis and experimental infection study. Lancet Microbe 2020, 1, e254-e262. [CrossRef]

129. Zlateva, K.T.; van Rijn, A.L.; Simmonds, P.; Coenjaerts, F.E.J.; van Loon, A.M.; Verheij, T.J.M.; de Vries, J.J.C.; Little, P.; Butler, C.C.; van Zwet, E.W.; et al. Molecular epidemiology and clinical impact of rhinovirus infections in adults during three epidemic seasons in 11 European countries (2007-2010). Thorax 2020, 75, 882-890. [CrossRef]

130. Nowak, M.D.; Sordillo, E.M.; Gitman, M.R.; Paniz Mondolfi, A.E. Co-infection in SARS-CoV-2 infected patients: Where are influenza virus and rhinovirus/enterovirus? J. Med. Virol. 2020. [CrossRef]

131. Iuliano, A.D.; Roguski, K.M.; Chang, H.H.; Muscatello, D.J.; Palekar, R.; Tempia, S.; Cohen, C.; Gran, J.M.; Schanzer, D.; Cowling, B.J.; et al. Estimates of global seasonal influenza-associated respiratory mortality: A modelling study. Lancet 2018, 391, 1285-1300. [CrossRef]

132. PAHO. Flu Net Home Page. 2010-2021. Available online: http:/ / ais.paho.org/phip/viz/ed_flu.asp (accessed on 4 June 2021).

133. Audi, A.; Allbrahim, M.; Kaddoura, M.; Hijazi, G.; Yassine, H.M.; Zaraket, H. Seasonality of respiratory viral infections: Will COVID-19 follow suit? Front. Public Health 2020, 8, 567184. [CrossRef] [PubMed]

134. Smit, A.J.; Fitchett, J.M.; Engelbrecht, F.A.; Scholes, R.J.; Dzhivhuho, G.; Sweijd, N.A. Winter is coming: A Southern Hemisphere perspective of the environmental drivers of SARS-CoV-2 and the potential seasonality of COVID-19. Int. J. Environ. Res. Public Health 2020, 17, 5634. [CrossRef] [PubMed]

135. Li, Y.; Wang, X.; Nair, H. Global seasonality of human seasonal coronaviruses: A clue for postpandemic circulating season of severe acute respiratory syndrome coronavirus 2? J. Infect. Dis. 2020, 222, 1090-1097. [CrossRef]

136. COVID-10 Dashboard by the Center for Systems Science and Engineering (CSSE) at Johns Hopkins University (JHU). Available online: https: / / coronavirus.jhu.edu/map.html (accessed on 20 July 2021).

137. Monto, A.S. The seasonality of rhinovirus infections and its implications for clinical recognition. Clin. Ther. 2002, 24, 1987-1997. [CrossRef]

138. Kamau, E.; Onyango, C.O.; Otieno, G.P.; Kiyuka, P.K.; Agoti, C.N.; Medley, G.F.; Cane, P.A.; Nokes, D.J.; Munywoki, P.K. An intensive, active surveillance reveals continuous invasion and high diversity of rhinovirus in households. J. Infect. Dis. 2019, 219, 1049-1057. [CrossRef] [PubMed]

139. Navarro-Marí, J.M.; Pérez-Ruiz, M.; Galán Montemayor, J.C.; Marcos Maeso, M.; Reina, J.; de Oña Navarro, M.; Cilla Eguiluz, C.G. Circulation of other respiratory viruses and viral co-infection during the 2009 pandemic influenza. Enferm. Infecc. Y Microbiol. Clin. 2012, 30 (Suppl. S4), 25-31. [CrossRef]

140. Costa, L.F.; Queiróz, D.A.; da Silveira, H.L.; Neto, M.B.; de Paula, N.T.; Oliveira, T.F.; Tolardo, A.L.; Yokosawa, J. Human rhinovirus and disease severity in children. Pediatrics 2014, 133, e312-e321. [CrossRef] [PubMed]

141. Leotte, J.; Trombetta, H.; Faggion, H.Z.; Almeida, B.M.; Nogueira, M.B.; Vidal, L.R.; Raboni, S.M. Impact and seasonality of human rhinovirus infection in hospitalized patients for two consecutive years. J. Pediatr. 2017, 93, 294-300. [CrossRef] [PubMed]

142. Gardinassi, L.G.; Simas, P.V.M.; Salomão, J.B.; Durigon, E.L.; Trevisan, D.M.Z.; Cordeiro, J.A.; Lacerda, M.N.; Rahal, P.; de Souz, F.P. Seasonality of viral respiratory infections in southeast of Brazil: The influence of temperature and air humidity. Braz. J. Microbiol. 2012, 43, 98-108. [CrossRef] 
143. Marcone, D.N.; Culasso, A.; Carballal, G.; Campos, R.; Echavarría, M. Genetic diversity and clinical impact of human rhinoviruses in hospitalized and outpatient children with acute respiratory infection, Argentina. J. Clin. Virol. 2014, 61, 558-564. [CrossRef]

144. Pierangeli, A.; Scagnolari, C.; Selvaggi, C.; Verzaro, S.; Spina, M.T.; Bresciani, E.; Antonelli, G.; Bertazzoni, G. Rhinovirus frequently detected in elderly adults attending an emergency department. J. Med. Virol. 2011, 83, 2043-2047. [CrossRef]

145. Pisareva, M.M.; Eder, V.A.; Buzitskaya, Z.V.; Musaeva, T.D.; Afanaseva, V.S.; Go, A.A.; Obraztsova, E.A.; Sukhovetskaya, V.F.; Komissarov, A.B. Etiological structure of influenza and other ARVI in St. Petersburg during epidemic seasons 2012-2016. Vopr. Virusol. 2018, 63, 233-239. [CrossRef]

146. Turunen, R.; Jartti, T.; Bochkov, Y.A.; Gern, J.E.; Vuorinen, T. Rhinovirus species and clinical characteristics in the first wheezing episode in children. J. Med. Virol. 2016, 88, 2059-2068. [CrossRef] [PubMed]

147. Jartti, T.; Lehtinen, P.; Vuorinen, T.; Osterback, R.; van den Hoogen, B.; Osterhaus, A.D.; Ruuskanen, O. Respiratory picornaviruses and respiratory syncytial virus as causative agents of acute expiratory wheezing in children. Emerg. Infect. Dis. 2004, 10, 1095-1101. [CrossRef]

148. Longtin, J.; Marchand-Austin, A.; Winter, A.L.; Patel, S.; Eshaghi, A.; Jamieson, F.; Low, D.E.; Gubbay, J.B. Rhinovirus outbreaks in long-term care facilities, Ontario, Canada. Emerg. Infect. Dis. 2010, 16, 1463-1465. [CrossRef] [PubMed]

149. Pappas, D.E.; Hendley, J.O.; Schwartz, R.H. Respiratory viral RNA on toys in pediatric office waiting rooms. Pediatric Infect. Dis. J. 2010, 29, 102-104. [CrossRef]

150. Arruda, E.; Pitkäranta, A.; Witek, T.J., Jr.; Doyle, C.A.; Hayden, F.G. Frequency and natural history of rhinovirus infections in adults during autumn. J. Clin. Microbiol. 1997, 35, 2864-2868. [CrossRef] [PubMed]

151. Kraft, C.S.; Jacob, J.T.; Sears, M.H.; Burd, E.M.; Caliendo, A.M.; Lyon, G.M. Severity of human rhinovirus infection in immunocompromised adults is similar to that of 2009 H1N1 influenza. J. Clin. Microbiol. 2012, 50, 1061-1063. [CrossRef] [PubMed]

152. Mackay, I.M.; Lambert, S.B.; McErlean, P.K.; Faux, C.E.; Arden, K.E.; Nissen, M.D.; Sloots, T.P. Prior evidence of putative novel rhinovirus species, Australia. Emerg. Infect. Dis. 2008, 14, 1823-1824. [CrossRef]

153. Hai le, T.; Bich, V.T.; Le, K.N.; Diep, N.T.; Phuc, P.H.; Hung, V.P.; Taylor, W.R.; Horby, P.; Liem, N.T.; Wertheim, H.F. Fatal respiratory infections associated with rhinovirus outbreak, Vietnam. Emerg. Infect. Dis. 2012, 18, 1886-1888. [CrossRef] [PubMed]

154. Li, X.; Li, J.; Meng, L.; Zhu, W.; Liu, X.; Yang, M.; Yu, D.; Niu, L.; Shen, X. Viral etiologies and epidemiology of patients with acute respiratory infections based on sentinel hospitals in Gansu Province, Northwest China, 2011-2015. J. Med. Virol. 2018, 90, 828-835. [CrossRef] [PubMed]

155. Zhao, Y.; Shen, J.; Wu, B.; Liu, G.; Lu, R.; Tan, W. Genotypic diversity and epidemiology of human rhinovirus among children with severe acute respiratory tract infection in Shanghai, 2013-2015. Front. Microbiol. 2018, 9, 1836. [CrossRef]

156. Mak, G.C.; Wong, A.H.; Ho, W.Y.; Lim, W. The impact of pandemic influenza A (H1N1) 2009 on the circulation of respiratory viruses 2009-2011. Influenza Other Respir. Viruses 2012, 6, e6-e10. [CrossRef] [PubMed]

157. Nakauchi, M.; Nagata, N.; Takayama, I.; Saito, S.; Kubo, H.; Kaida, A.; Oba, K.; Odagiri, T.; Kageyama, T. Propagation of rhinovirus $C$ in differentiated immortalized human airway HBEC3-KT epithelial cells. Viruses 2019, 11. [CrossRef] [PubMed]

158. Esposito, S.; Daleno, C.; Baggi, E.; Ciarmoli, E.; Lavizzari, A.; Pierro, M.; Semino, M.; Groppo, M.; Scala, A.; Terranova, L.; et al. Circulation of different rhinovirus groups among children with lower respiratory tract infection in Kiremba, Burundi. Eur. J. Clin. Microbiol. Infect. Dis. 2012, 31, 3251-3256. [CrossRef] [PubMed]

159. Famoroti, T.; Sibanda, W.; Ndung'u, T. Prevalence and seasonality of common viral respiratory pathogens, including Cytomegalovirus in children, between $0-5$ years of age in KwaZulu-Natal, an HIV endemic province in South Africa. BMC Pediatr. 2018, 18, 240. [CrossRef]

160. Warshauer, D.M.; Dick, E.C.; Mandel, A.D.; Flynn, T.C.; Jerde, R.S. Rhinovirus infections in an isolated antarctic station. Transmission of the viruses and susceptibility of the population. Am. J. Epidemiol. 1989, 129, 319-340. [CrossRef]

161. WHO. Influenza Updates. Available online: https://www.who.int/influenza/surveillance_monitoring/updates/en/ (accessed on 11 February 2021).

162. Poole, S.; Brendish, N.J.; Clark, T.W. SARS-CoV-2 has displaced other seasonal respiratory viruses: Results from a prospective cohort study. J. Infect. 2020. [CrossRef]

163. Ånestad, G.; Nordbø, S.A. Virus interference. Did rhinoviruses activity hamper the progress of the 2009 influenza A (H1N1) pandemic in Norway? Med. Hypotheses 2011, 77, 1132-1134. [CrossRef]

164. Casalegno, J.S.; Ottmann, M.; Bouscambert-Duchamp, M.; Valette, M.; Morfin, F.; Lina, B. Impact of the 2009 influenza A(H1N1) pandemic wave on the pattern of hibernal respiratory virus epidemics, France, 2009. Euro Surveill. 2010, 15, 19485. [CrossRef]

165. Anderson, R.M.; Fraser, C.; Ghani, A.C.; Donnelly, C.A.; Riley, S.; Ferguson, N.M.; Leung, G.M.; Lam, T.H.; Hedley, A.J. Epidemiology, transmission dynamics and control of SARS: The 2002-2003 epidemic. Philos. Trans. R. Soc. 2004, 359, $1091-1105$. [CrossRef]

166. Nickbakhsh, S.; Mair, C.; Matthews, L.; Reeve, R.; Johnson, P.C.D.; Thorburn, F.; von Wissmann, B.; Reynolds, A.; McMenamin, J.; Gunson, R.N.; et al. Virus-virus interactions impact the population dynamics of influenza and the common cold. Proc. Natl. Acad. Sci. USA 2019, 116, 27142-27150. [CrossRef]

167. Jartti, T.; Jartti, L.; Peltola, V.; Waris, M.; Ruuskanen, O. Identification of respiratory viruses in asymptomatic subjects: Asymptomatic respiratory viral infections. Pediatric Infect. Dis. J. 2008, 27, 1103-1107. [CrossRef] 
168. Wolsk, H.M.; Følsgaard, N.V.; Birch, S.; Brix, S.; Hansel, T.T.; Johnston, S.L.; Kebadze, T.; Chawes, B.L.; Bønnelykke, K.; Bisgaard, H. Picornavirus-induced airway mucosa immune profile in asymptomatic neonates. J. Infect. Dis. 2016, 213, 1262-1270. [CrossRef] [PubMed]

169. Makris, S.; Johnston, S. Recent advances in understanding rhinovirus immunity. F1000Research 2018, 7. [CrossRef] [PubMed]

170. Bar-On, Y.M.; Flamholz, A.; Phillips, R.; Milo, R. SARS-CoV-2 (COVID-19) by the numbers. eLife 2020, 9, e57309. [CrossRef]

171. Sanjuán, R.; Nebot, M.R.; Chirico, N.; Mansky, L.M.; Belshaw, R. Viral mutation rates. J. Virol. 2010, 84, 9733-9748. [CrossRef] [PubMed]

172. WHO. Influenza (Seasonal). Available online: https://www.who.int/news-room/fact-sheets/detail/influenza-(seasonal) (accessed on 18 May 2021).

173. Mandal, A. COVID-19 Pandemic Is “One Big Wave” Says WHO. Available online: https://www.news-medical.net/news/202007 30/COVID-19-pandemic-is-one-big-wave-says-WHO.aspx (accessed on 22 July 2021).

174. Aboubakr, H.A.; Sharafeldin, T.A.; Goyal, S.M. Stability of SARS-CoV-2 and other coronaviruses in the environment and on common touch surfaces and the influence of climatic conditions: A review. Transbound. Emerg. Dis. 2021, 68, 296-312. [CrossRef] [PubMed]

175. Cimolai, N. Complicating infections associated with common endemic human respiratory coronaviruses. Health Secur. 2021, 19, 195-208. [CrossRef] [PubMed]

176. Dreschers, S.; Dumitru, C.A.; Adams, C.; Gulbins, E. The cold case: Are rhinoviruses perfectly adapted pathogens? Cell. Mol. Life Sci. 2007, 64, 181-191. [CrossRef]

177. Fendrick, A.M.; Monto, A.S.; Nightengale, B.; Sarnes, M. The economic burden of non-influenza-related viral respiratory tract infection in the United States. Arch. Intern. Med. 2003, 163, 487-494. [CrossRef] 